\title{
Language in the Constitution of Kinship
}

\section{Ian Keen}

\begin{abstract}
Kinship has been an "essentially contested concept" in social and cultural anthropology. Nevertheless, linguistic and anthropological linguistic studies of kinship terminologies, grammar, and pragmatics have developed in parallel with anthropological ones. Lacking, however, is a broad overview of the range of linguistic variation across languages that would build a bridge between the linguistics and anthropology of kinship. Toward that end, this article explores the role of language in the constitution of kinship. It asks, on what linguistic resources do people of different cultures and languages draw in order to constitute kinship as an institution?
\end{abstract}

\section{Introduction}

Kinship has been an "essentially contested concept" (Gaille 1955-6) in cultural and social anthropology. Not only has the topic moved away from center stage since the 1970s, but there has been a shift from analyses in terms of seemingly universal types of institution toward a focus on "practice" (Carsten 2000:2). Doubt has been cast on the validity of classifying types of society in terms of kinship (as in "matrilineal societies"), the cultural 
salience of kinship as a category, and on its utility in cross-cultural translation (e.g. Schneider 1984; Needham 1971). Connections resulting in enduring relations have been found to be far more diverse than "biological" relations (Godelier 2011; Sahlins 2012). Not least, the field of the family in industrial societies has been extended through changes in the constitution of domestic groups, as well as in technologies of reproduction, leading to new varieties of parenthood and resulting relations (Carsten 2004; Strathern 2011). To accommodate such changes some scholars have substituted the broader concept of "cultures of relatedness" for “kinship" (Carsten 2000).

In spite of these debates, there is a vast and growing ethnographic corpus describing what ethnographers categorise as kinship in a wide array of cultures. On a parallel trajectory, linguists have provided accounts of kinship vocabularies and expressions in a wide range of languages, and linguistic anthropologists have provided insights into the pragmatics of kinship discourse. The debates suggest that it would be inappropriate to try to specify universal necessary and sufficient conditions for applying the analytical category "kinship" cross-culturally. "Kinship" nevertheless remains a useful concept for cross-cultural comparison and analysis, for there is a family resemblance (Wittgenstein 1953) among what anthropologists and linguists have identified as kinship phenomena across cultures.

Drawing on anthropological and linguistic sources, following a related exercise on the language of possession and property (Keen 2013), this article examines the linguistic resources that are brought to bear in constituting what ethnographers and linguists have identified as kinship (or indeed as "relatedness") in a wide variety of cultures. This exercise may clarify just what is shared by socio-cultural domains categorised by analysts as kinship (or parenté, Verwandtschaft etc.), and some of the ways in which they vary. It is also 
intended to build a bridge between anthropological approaches to kinship and relatedness, on the one hand, and linguistic and anthropological-linguistic accounts of kinship terminologies, grammar, and pragmatics, which have developed in parallel. The article is primarily concerned with kinship categories and metacategories, and not with the forms of kinship terminologies, Nor is it concerned with marriage, or with patterns of marriage alliance (e.g. Barry 1998), or group exogamy and endogamy (e.g. Barry 2000), except as they impinge in one or two cases on the classification of kin.

I propose the following cognitive and linguistic requisites for the constitution of kin relations:

- The cognitive capacity to understand relational categories

- A lexicon of kin terms distinct from other social categories

- Means of identifying the propositus (or anchor - the person whose relation is being referred to) and referent, and of denoting a connection between them ${ }^{1}$

- Means of expressing criteria for the application of kin terms for address, reference and predication

- Shared cognitive schemas through which kin terms are mapped on to persons and represented spatially and visually

- Constitutive practices through which kin relations are enacted

\section{Relational categories}

In order to constitute kinship we need to be able to express relations by means of categories which connect two or more entities (Levinson 2010:392). The qualities of relations, however, 
are very diverse (Anggoro et al. 2005; Gentner \& Kurtz 2005; Doumas et al. 2008). Chit Hlaing (Lehmann) (2001:256) regards kinship and the most purely relational among kinds of social relations. Kinship categories exhibit a particular kind of relationality, however - they are person centric. Kin relational expressions such as my mother "point" from a propositus to a referent, who may be a speech act participant in predicative (1a) and vocative uses of kin terms (1b), or a non participant in referential (1c) and predicative uses such as "Alison is Imogen's cousin".

\title{
(1a) Japangardi, ngu laju Japanangka-ku jaji-nyanu
} [subsection name] he is [subsection name]-DAT father-ANAPH 'Japangardi, he is Japanangka's father.' (Warlpiri; Laughren 1982:73)

\author{
(1b) pitā-r \\ father-VOC \\ 'father!' (Sanskrit; Agha 2007:351) \\ (1c) pitā
father (Sanskrit; Agha 2007:351)
}

Each kin relational category has a semantic inverse or reciprocal: if A is B's relative then B is A's relative (Agha 2007:346). Children gradually master the relational character of kin relational expressions after their early use as something like proper names (e.g. Haviland and Clark 1974; Price-Williams et al. 1977:322-3; Ragnarsdóttir 1999). 
It is misleading to say that kinship terminologies are "ego centric," for kin relations can be viewed from the "outside" as it were (Sahlins 2012:25). To be sure, a person is someone's kinsperson, but two people are related as, for example, brother and sister from anyone's point of view. A kinship relation always partakes in a field of interconnected relations, in which relations are triangulated (Levinson 2007) - Em was my aunt, Joyce is her daughter, and Joyce and I are cousins. Triangulation is not always complete, however - Tom is my cousin through his father, who was my mother's brother, but Tom's cousin through his mother is not my cousin, although at a pinch we could classify each other as cousin's cousin. Triangulation in discourse appears to be most comprehensive in social worlds in which most people count as kin and one marries a kinsperson.

\section{Kinship lexicons}

The constitution of kinship requires a lexicon that identifies kin in contrast with non kin, and differentiates one kind of kinsperson from another. The number of distinctions that terminologies make between kinds of kin varies considerably from a handful in Pirahã (Everett 2005) to comparatively many; there are more than sixty in Bastar (central India) for example (Gregory 2012).

A kin term lexicon is not wholly discrete, for languages borrow from other domains to constitute kin terms and lend them to other domains, for example child, boy, and girl in English (Dahl and Koptyevtskaja-Tamm 2001), joogoo ('offspring', 'child') in Gooniyandi (McGregor 2012:165), and 'my little pet son' for BS in northeastern Algonkian (Speck 1918:151), 'liitle one' (nana) for younger sister in Kutenai (Boas 1919:99); 'my old head' ( $k$ - 
kran-tum ) for MB, MF and FF in Kayapó and 'young head' (kran-nu) for their reciprocals (Turner 2012:224). In Jarawa (Nothern Nigeria) expressions were borrowed from neighbouring languages to denote certain kin, such as abokin wasa 'play friend' (Hausa) to denote a variety of cross-cousins (Conant 1961:23).

In Nez Perce (Aoki 1966:360) some polymorphemic kin/affinal terms are derived from metaphors. For example, the term for 'husband's brother's wife' (pe'ékstiwe') derives from pe'ékswise, 'I am jealous' and its cognate pípe'kswit, 'rivalry', together with $m / t i w e-$, 'those who have things in common'. In Atsugewi great-grandparents and great-grandchildren were referred to as asmuk, 'my ear', seemingly because these relatives would report hearing anything against the person (Garth 1944:351). Teknonymy structures kin terms in some languages. A Kutenai woman's father-in-law is her 'child's grandfather'; her mother in law is her 'daughter's grandmother' (Sapir 1918:418). Feng (1936) argues that teknonymy drove certain aspects of the evolution of the Chinese kinship terminology.

Many languages have variant terms for the same kinsperson, used for several purposes: reference and address, baby talk, to denote a bereaved relative, or for endearment or derision (2 a-d).

(2a) anherr-anherr aray, nhey-nhey ngkwenh HM/ZSW-redup look:IMP HM/ZSW(dimin) 2sgPoss 'Look at your mother-in-law, your “mummy-in-law”!' (Anmatjirra; Green 1998:38)

\section{(2b) twistan}

stepfather (somewhat derisive) 


$$
\begin{aligned}
& \text { (2c) } s k^{, w} u y \\
& \text { mother (reference) }
\end{aligned}
$$

$s k^{, w} k^{\prime w} u y$ 'mother' (male propositus, hypocoristic apellative) (Okanagan-Colville; Mattina and Jack 1992:121)

(2d) na'iłas
my mother

aDdwa'ina'i’tas

my deceased mother (Sahaptin; Jacobs 1932:689)

Most address terms in Acoma Keresan (New Mexico) are based on reference terms (Miller 1959). Vocative forms of kin terms in Bankalawa-Jarawa kin terms made more complex social discriminations than did reference terms (Conant 1961:21), as they do in Bastar (Gregory 2012; pers. com.). Grammatically, alternative forms may behave differently from the standard ones. In certain contexts the familiar kin term papa ('dad') in French, for example, does not require the otherwise obligatory possessive article as in mon père ('my father', Dahl and Koptjevskaja-Tamm 2001:218).

The morphology of kin terms 
Kin terms vary morphologically from unanalysable lexemes such as mother, through analysable compound forms such as grandmother, to multilexic terms such as brother in law. Anthropological records of kin terms may obscure these distinctions: all but two of the nineteen apparently monomorphemic or monolexemic Seneca kin terms are composed of a root preceded by a regular pronominal prefix, and twelve consist of a regular transitive prefix followed by a transitive verb root (Kay 1975:203-4).

Dilexic and trilexic terms consist of strings of kin terms (3a-c) or a kin term or expression plus a modifier indicating, for example, gender, generation, collateral and step kin $(4 a-g)$.

(3a) pinsedn pusud

cousin sibling (children of intermarrying sibling pairs)

(Banggi; Boutin 1984:306)

(3b) dayí çocuğu

mother's brother son

‘cross-cousin' (rural Turkish; Casson 1978:361)

(3c) nokomiss grandmother

nindanika nokomiss great grandmother

(Ojibwa: Trautmann and Barnes 1998:36) 
high father's father

FFFF (Classical Chinese; Chen and Shyrock 1932:631-2)

$(4 \mathrm{e})$

apuq $\quad \mathrm{PF}, \mathrm{CS}$

apuq kese All male kin of PF's and CS's generations.

apuq kudue All male kin of PPF's and CCS's generations

apuq kelime All male kin of PPPPPF's and CCCCCS's generations

(Banggi; Boutin 1984:307)

(4f)

tanúm káyáak

my brother associate

“paternal parallel cousin” (Telefol; Healey 1962:21)

(4g) $\quad k^{w} \partial l^{\prime}-t-k k^{\prime} i k^{\prime} w a ?$

make/do-CONN-grandfather

'step grandfather' (Okanagan-Colville; Mattina and Jack 1992:133)

Kin terms may also be modified discursively, and not as an intrinsic part of the kin relational expression. Among Yolngu people, for example, siblingship may be qualified as "same father, same mother" or "same mother, different fathers" and so on (Shapiro 1981).

Dyadic or binary kin terms denote both parties in a reciprocal kin relation, such as husband and wife or mother and son in English. In Yolngu languages the senior term (where 
applicable) is chosen (5a), but in Gooniyandi a choice has often to be made (5b) (McGregor 1996:221-2). In the Arrernte example (5c) the reciprocal kin relation obtains between two “countries.” Among the Wind River Shoshone (Shimkin 1941:227) the expressions for 'parent-and-child,' 'elder-and-younger brother', 'elder-and-younger sister', and 'husbandand-wife' consist of the reciprocal nana- prefixed to the emphasized member of the relationship (5d).

(5a) wa:wa'-manydji

eB-RECIP

'brothers'

dhuway'-manydji

FZC- RECIP

FZC-MBC (Gupapuyngu; Zorc 1986)

(5b) jaja-langi

MM-wDC (Gooniyandi; McGregor 1996:220-21)

(5c) Pmere nhenhe therre kenhe ke-nhenge therre

place this two BUT eld.brother-DYADIC two

y'know, pmere nhenhe re bak-arteke arrpenhe ikwere

y'know place this 3SgS eld.brother-SEMBL other 3SgDAT 
'These two places, on the other hand, are two brothers together (i.e. are two brothers to one another); you know what I mean, this place is like the elder brother to the other one.' (Arrernte; Wilkins 1993:78)

$(5 \mathrm{~d})$

$$
\begin{aligned}
& \text { na'nadu'a }(-n u x,-n e) . \quad \text { s-and-f } \quad \text { (ndúa, 'son') } \\
& n a^{\prime} n a p \ddot{e}^{b} \quad \text { f-and-s } \quad(a: \text { 'pë, 'father') } \\
& \text { nanabe'di- } \quad \mathrm{d} \text {-and-m } \quad \text { (mbe'de, 'daughter') (Wind River }
\end{aligned}
$$

Shoshone (Shimkin 1941:227)

Where two different kin term are applicable to the same referent through distinct paths of connection in Korowai they may be paired, as in mom-sabül ('uncle-nephew') for example (Stasch pers. com.). Yolngu employ the metaphor yothu-yindi ('child-large') for reciprocal mother-child relations (Zorc 1986).

\section{$\underline{\text { Kinship meta categories }}$}

Kinship lexicons include explicit meta categories, suggesting that speakers are aware of the forms of their terminologies. Concepts of kin as a class, such as "relatives" in English, are very common and perhaps universal (Examples 6a-6g).

(6a) lambil, 'relatives' (Korowai, West Papua; Stasch 2009:106)

(6b) $a_{a}$ 'kınık'na'mo (Kutenai, derived from -akinık', 'parents'; Boas 1919:99) 
(6c) ilyatka, 'kindred' (Inuit; Pospisil and Laughlin 1963:187); ilagiit 'kin,' ila, 'kin,' 'those who accompany' (Nunavut, Trott 2005:1)

(6d) nabu, 'kin,' nukun nabu 'all the Cashinahua' (Cashinahua [Amazon]; McCallum 1990:416)

(6e) sanqsilx ${ }^{w}$, 'one’s people' (Okanagan-Colville; Mattina and Jack 1992:118)

(6f) akraba, 'kinsperson/s,' 'relative/s' (rural Turkish; Casson 1973:294)

(6g) clann, 'family' (Gaelic; Lele 2009:109)

Relatives are indicated by a suffix in Arandic languages (Central Australia) (7).

(7) Any-ankethenhe map-ele atwetjalaye, lhampwe

F-kin:having group-ERB hit:NegIMP orphan

'You lot have got a father, don't beat him up, he’s an orphan' (East and

Central Arrernte; Green 1998:39 citing Henderson and Dobson 1994:145)

In many languages the category RELATIVE contrasts with NON RELATIVE (8a-c), and in many languages with AFFINE (9a-e). No term denotes kinship as a field in Nez Perce, in 
which meta categories are found only for parts of the field, such as wiwayko' 'offspring' (Aoki 1966:357).

(8a) gurrutu 'relative,' mulkuru 'stranger' (Yolngu; Zorc 1986)

(8b) duubafin, 'relatives,' fakaniing, 'non-relatives' (Telefol; Healey 1962:24)

(8c) ombikwa [õ-bi-kwo], 'kin,' mẽbaitebm, 'non-kin' (Kayapó; Bamberger 2009:1044)

(9a) relatives by blood, in-laws or relatives by marriage (English)

(9b) parents ('kin'), beaux-parents ('in-laws') (French)

(9c) nikushin 'blood relative,' inzoku 'in-law' (Japanese; Wallace and Atkins 1969)

(9d) akraba/lar (relative/s), hísím/lar ('affines' including step-kin), kayín or kayinlar ('inlaw': spouse's parents and spouse's siblings) (rural Turkish; Casson 1973:294, 1978:361; Busch 1980:43)

(9e) $\tilde{o}-b i-k w o$, 'one’s surrounding curved space', 'kindred', 'kinship' aben wòrò mõrõ kan õ bi-kwa, 'kinship by marriage', 'affinity' (Kayapó; Turner 2012:223-4) 
The LINEAL-COLLATERAL contrast is explicit in English and implicit in Chinese modifiers (10). The meta category GENERATION is implicit in the Urarina terminology (11a) and explicit in English, and is salient in Australian Western Desert generation moieties (11b). Like English, Japanese has a concept of SIDE in kinship (see $31 \mathrm{k}$ below).

(10) pao lineal relations

t'ang father's father's collateral kin

tsai 'attend,' 'follow' - FFF's collateral kin

tsu 'thrice venerated' - FFFF's collateral kin

wai 'outside,' 'foreign' - kin of the mother's clan. (Classical Chinese; Chen and Shyrock 1932:625, 650-1)

(11a) $\mathrm{G}+2$ canu rinajauru

'my grandparents'

$\mathrm{G}+1 / 2$ canu coitucueracuru

'those who know me'

$\mathrm{G}+1$ canu jojiarauru canu jojiarauru rijijieein nena

'those who raised me' 'those who are like those who raised me'

G0 canu nejerauru canu nejerauru rijijieein nena

'my siblings' 'those who are like my siblings'

G-1 canu berecuru canu berecuru rijijieein nena

'my children' 'those who are like my children'

G-2 canu ichoalacuru 
‘my grandchildren' (Urarina; Walker 2009:58)

(11b) nganantarka own, PP, and CC generation

tjanamilytjan P, C generations (Pitjantjatjara; Keen 2004)

tjuntultukultul ('sun side')

ngumpaluru ('shade side') (Ngaatjatjara; Keen 2004)

The PARALLEL-CROSS distinction appears salient in Ese-Ejja (Lepri 2005), and is a key feature of Dravidian systems (Kronenfeld 2001). An AVOIDED category is found in many Australian languages (12a-b), and in Bastar (12c).

(12a) nginarr 'avoidable' kinsperson

pipi nginarr 'avoidable' FZ

pipi yutjpan 'straight' FZ, not avoided (Murriny-Patha; Blythe 2010a:8)

(12b) ganji, ngalamu', malbung 'avoided relative' (Mangarrayi; Merlan 1982:131)

(12c) susara 'avoidance relation' (Bastar; Gregory 2012:199) 
Aoki argues (1966:358) that the morphology of Nez Perce kin terms tacitly divides a person's relatives into senior and junior consanguineal kin, and affines. There are also explicit meta-categories which fit these distinctions (1966:360) (13).

\begin{tabular}{|c|c|}
\hline titílo & senior kinspersons, ancestors \\
\hline nícu & junior kinspersons \\
\hline wiwáyko' & 'young twig, branch of tree', descendants \\
\hline himíyu & blood relative (Nez Perce; Aoki 1966) \\
\hline
\end{tabular}

The KINDRED as an egocentric network and quasi group has appeared in many societies. For example muintir ('people') denotes a kindred concept in Gaelic (Lele 2009:109), and membership of one's kindred is marked in Bastar (central India) by the familial salute (Gregory 2012:196). Distinctions between CLOSE and DISTANT kin are very widespread. Moalans, for example, distinguished between 'very true' relatives (having a common grandparent), 'true relatives' and distant 'relatives by descent' (Sahlins 1962:157). In Dyirbal the woman who gave birth to one is one's yabu ('mother') while others classified as "mother" are yabu jarraga or simply jarraga (Dixon 1989:247). Kayapó distinguish 'true' (kumren) kin from more distantly related relatives (Turner 2012:224).

Reckoning of kinship distance among the Navajo does not give equal weight to mother-child and father-child relations, as in some anthropological models, according to Witherspoon:

Only the relationship of husband-wife and mother-child are primary, and involve no connecting category. The relationships of father-child and sibling-sibling and 
maternal grandmother-maternal grandchild are all connected by one category, the mother. These are secondary relationships. Ego and his paternal grandmother and maternal grandmother's husband, children, or mother (ego's maternal greatgrandmother), are all relationships of the third order, and so on. (Witherspoon $1975: 54)$

One's 'father' is evidently construed as 'mother's husband' in this system.

Categories taken to be kinship "superclasses" (Scheffler 1978:60) may perhaps be treated as meta categories. These arise where kinship categories are merged for the purpose of mourning designs, for example, or where people aver that one's mother's mother's brother is a kind of brother (Scheffler 1978:296). I am inclined to treat the Karembola categorisation of mother's brothers as "male mothers" as meta categorial. These relatives are seen as the source (foto) of the fecundity of their sisters' children (Middleton 2000:108), and 'make the child live' (mameloñe anake). Men describe their sisters' sons as 'born from their own belly' (an-troke teña) and as 'crying for their breast' (motomany ty nono) (2000:112).

Meta categories are often important in the relationship between kin classification and other discourses and institutions. For example the contrast between 'same' and 'non same' relatives among Ese-Ejja people (Lepri 2005) has to do with cross cousin marriage and affinity, and kinship distance is relevant to marriageability in Australia. The lineal-collateral contrast comes into play in English inheritance, and is relevant to inheritance tax in the US and Uganda (Benschop 2002:86). Meta discourses of kin relatedness include their characterisation in terms of 'blood,' 'milk' and the body (Godelier 2011; Sahlins 2012), linking kinship to ontologies and cosmologies. 


\section{Propositus, referent and the connection between them}

The expression of a kin relation between people requires the relational categories themselves, and means of differentiating the propositus from the referent. The propositus of a kin relational expression may be identified by means of a social category within a descriptive referring expression (the cyclist's aunt), a proper name (John's mother), a possessive pronoun (his mother), or a kin relational expression (my mother's brother). The propositus may be marked for gender and number, and qualified in several ways (e.g. the rain soaked cyclist's aunt). In vocative usages such as 'Mum!' the propositus or anchor is implicit and context dependent (Jonsson 2001:1204-5). The location of the propositus varies between indirect uses of kin terms, reciprocal expressions such as two brothers, and trirelational terms (see below). The referent may be denoted by a kin term or by a kin term plus a name or pronoun (my uncle Charles). Some languages permit omission of the referent and retention of the indicator of a connection, as in 'hers' rather than 'her child' (Blythe 2010a:44).

Linguistic means of conveying a connection between the propositus and the referent include juxtaposition, case marking, modification of the stem, clitics, pronominal affixes, prepositions, pronouns and possessive adjectives. These may involve marking on the head of

a kin relational expression (Table 1a-f), dependent marking (Table 1g-i), and marking on neither the head nor the dependent (Table 1j-1) (Nichols 1986).

[Insert Table 1 approximately here] 
The possession of kin is often treated differently from other objects of possession as inalienable possession (in the linguistic sense), distinct from alienable possession (Young and Morgan 1980:28). In many languages, both related and unrelated, such as Koya (Tyler 1965), Navajo (Young and Morgan 1980), Kutenai (Garvin 1951:88) and Nez Perce (Aoki 1966:357), pronominal affixes on kin terms are obligatory (e.g. Table 1a), and it is often this feature that marks inalienable possession (e.g. Mathews 1959:253)

All these various means of indicating a connection between propositus and referent do the same kind of work. The precise nature of the connection is implicit, carried in the criteria for the application of kin terms, discussed below.

\section{The grammar of kin terms}

The grammar of kin terms varies with that of the embedding languages, while some languages have unusual forms such as kin dependent pronouns and kinship verbs. The formation of plurals provides an example of variation. Kin terms in Telefol take a plural suffix while most nouns do not (Healey 1962:19). In Coast Salish the five ways of forming plurals include the addition of a prefix to the stem and reduplication (Mattina and Jack 1992:126). Plural forms of kin terms in Spanish are in the masculine gender (Mestheneos and Svensson-Dianellon n.d.). In Älvdalen Dalecarlian (Germanic) some kin terms lack a plural form, whereas masculine animate nouns in Polish, including kin terms, take a special plural ending (Dahl and Koptjevskaja Tamm 2001:209). The plural form in English indicates the dyadic relationship between same sex siblings, siblings in law and cousins, as in "We are cousins." 
Kin terms in Kutenai require pronominal suffixes (Garvin 1951:88), but it is inappropriate to attach the indefinite possessive suffix -nam to the root to form 'someone's K', for example *ma'nam 'someone's mother'. The form nana'-nam, 'someone's younger sister', became accepted in the sense of 'nun', however. Vocatives without a pronominal suffix (14a) were uncommon in Kutenai (Boas 1919:100); the vocative form for 'father' includes a pronominal prefix $g a$, as do 'grandmother' and 'younger brother' (Boas 1919:100; Sapir 1918) (14b).

$(14 a)$

$$
\begin{array}{ll}
\text { tsú’à } & \text { 'younger sister!' } \\
\text { xaleine } & \text { 'son!' } \\
\text { pa't' } & \text { 'nephew!' (Kutenai: Boas 1919:100) } \\
& \\
\text { ga-d'to } & \text { 'my father' (Kutenai; Sapir 1918:414) }
\end{array}
$$

The Q'eqchi' noun class marker - bej for inalienable possessions is elided when a kin term is modified by a possessive pronominal prefix (Kockelman 2007: 345) (15).
(15) na’bej
mother-CLF
'mother'
in-na'
POS-mother 
'my mother' (Q'eqchi', Kockelman 2007: 345)

Nez Perce kin terms take vocative suffixes as well as possessive suffixes, and the object case suffix which indicates non-possession. Vocative suffixes have senior and junior forms (Aoki 1966:357-8). In Acoma Keresan, most address terms are based on reference terms (Miller 1959). Inalienably possessed terms are used with the first person pronominal prefix, while alienably possessed terms are use with or without the pronominal prefix, with the exception of s'ama't'i ('my son') which, in spite of being an alienably possessed noun, must be used with the first person pronominal prefix. The root ama' $t$ ' $i$ denotes 'boy' or 'young man', an alienable noun, while s'ámá'áka ('my daughter') is irregularly derived from maga' 'small girl' (Miller 1959:180).

In French the reference form of a kin term, but not the vocative, requires a pronoun (see above), and in Italian the definite article is omitted from kin relational expressions, in contrast with other nouns (16).

la mia casa

the my house

'My house'

mio padre

'My father' (Italian, Dahl and Koptjevskaja-Tamm 2001:205) 
Each referential kin term in Ngarinyin (northwestern Australia) is suffixed to indicate the number (singular or plural) of the referent, and the person and number of the propositus The suffixes are added to a base that in most cases is identical to the vocative form (Rumsey 1981:156) (17).

\begin{tabular}{|c|c|c|c|}
\hline garndingi & 'my uncle' & garndingirri & 'my uncles' \\
\hline garndini & 'your uncle' & garndinirri & 'your uncles' \\
\hline garndinangga & 'his/her uncle' & garndanggarri & 'his/her uncles' \\
\hline garndingarruna & 'your and my uncle' & garndingarrumbu & 'your and my uncles' \\
\hline garndinyarruna & 'our uncle [excl.]' & garndinyarrumbu & 'our uncles [excl.]' \\
\hline garndinudna & 'you people's uncle' & garndinurrumbu & 'you people's uncles' \\
\hline garndiduga & 'their uncle' & garndirrumbu & 'their uncles' \\
\hline
\end{tabular}

(Ngarinyin; Rumsey 1981:156)

Some Australian languages have systems of pronouns in which the form of the non singular pronoun depends on the kin relationship between the referents. Dual pronominal prefixes in Dalabon, for example (Alpher 1982:20) (18a), mark person, number and the dimension INCLUSIVE -EXCLUSIVE. Two sets relate to the relative generation level of the two persons referred to. The HARMONIC set applies to pairs of persons of the same generation level or who are separated by an even number of generations $(+2,-2)$; the DISHARMONIC set applies to pairs of persons separated by an odd number of generations $(+1,-1,+3,-3)$. Non marriageable cross cousins are treated as "disharmonic" relatives, as are pairs of inanimate 
objects and non Aboriginal people (Alpher 1982:21). Warlpiri marks pronouns for harmonic and disharmonic generations in a similar way (Hale 1966) (18b). The Kaytej language marks pronouns for generation and patri moiety on the basis of either a kin or a section/subsection relation (Koch 1982:68). These systems, then, depend upon a covert metacategory of GENERATION.

$$
\begin{array}{ll}
\text { Harmonic } & \text { Disharmonic } \\
\text { generation } & \text { generation }
\end{array}
$$

1DuEx yarrah- ngeh-

1DuIn yah- djeh-

2Du narrah- deh-

3Du barrah- geh- (Dalabon, Alpher 1982:20)

(18b) (a) karan-kur wa n-kur ki-rri

(where-future go-future you-dual:harmonic)

(b) karan-kur wa n-kur nyi-nki

(where-future go-future you dual:disharmonic)

'Where will you two go?'

(Hale 1966; cited in Wierzbicka 1986:37) 


\section{Kinship verbs}

In several languages kin relations are denoted by verbs as well as nouns and nominals. In various North American and Australian languages kinship verbs have the sense 'be K of,' 'have someone as K,' 'call someone K,' or 'consider as K,' where K is a kin term (Kay 1975; Jonsson 2001:1211; Evans and Birch 2007) (20a-c).

Iwaidja (northern Australia) kinship verbs are semantically more general than kinship nouns; for example 'be-mother-to' encompasses M-wC, MZ-wZC and MB-mZC (19a-b). They refer to close rather than distant kin, and are preferred in the denotation of kinship dyads. The same verb can denote either party in a relationship; for example wulang ('bemother-to') can denote either the mother or the child (Evans and Birch 2007). Kinship verbs in Yuma (California) (19c) comprise the majority of kin terms, while kinship nouns representing the remainder including $\mathrm{mF}$ and $\mathrm{wC}$. Yuma kinship nouns may be converted to verbs with the addition of a suffix, however (Halpern 1942). Twelve of the nineteen Seneca kin-relational expressions consist of a transitive pronominal prefix followed by a transitive verb root, and so comprise simple transitive sentences (Kay 1975:204-7) (19d). In Kiowa Apache the term for 'father' (- 'à cé) is modified to denote 'stepfather' (- 'àcénádídli), glossed by Eggan (1955:105) as 'he becomes father'.

(19a) ngandu-wula-ng 3A $>1$ sgO-be.mother.to-P (Iwaidja; Evans and Birch 2007:9)

(19b) 'Nuyi kabana-wun nuyi kaK-mana-wu-n ngabi ngandu-wulang, ngabi ngandu-wula-ng 
2sg 2sgA $>3$ sgO-IRR-kill-NPst 1 sg $\quad 3 \mathrm{~A}>1$ sgO-be.mother.to-PP

lda ngabiabana-wun nuyi kundu-wulang!

lda ngabi aK-mana-wu-n nuyi kundu-wula-ng

and $1 \mathrm{sg} \quad 1 \mathrm{sg} \mathrm{A}>3 \mathrm{sgO}$. IRR-kill-NPst $2 \mathrm{sg} 3 \mathrm{~A}>2 \mathrm{sgO}$-be.mother.to-PPst

'You kill my mother, and I'll kill your mother!'

Lit. 'you kill her (such that) she is mother to me, and I will kill her

(such that) she is mother to you.' (Iwaidja; Evans and Birch 2007:1)

(19c) * $u$-x'-ami', 'to procreate, to be the father of' (Yuma; Halpern 1942:426)

(19d) 'akso:t, 'she GRANDPARENT me' (root - hso:t, 'be grandparent to') (Seneca; Kay 1975:207)

\section{Complex kin relational expressions}

Complex kin relational expressions such as altercentric, tri relational and polyadic terms build on the networks of relations established by more basic kin terms, and exploit the cognitive capacity for taking multiple points of view within a field of relations.

Yolngu (northern Australia) altercentric forms include nganakal, 'your mother's brother' (the referential form is ngapipi or gawal) and ngananawa, 'your MBC' (the referential form is galay) (Zorc 1986; cf. Merlan 1982 on Mangarrayi). Trirelational or triadic kin terms encode both the relationship between speaker and addressee (or some other 
kinsperson as reference point), and the relation of that person (as reference point) to the referent (McConvell and Obata n.d.), building on triangulation created by basic kin terms (19). The term kuyarri-marnany in the Gurindji language (north central Australia), for example, can be glossed as 'with reference to you, my mother's mother - your brother'.

(19) Addressee is $\mathrm{B} / \mathrm{FF} / \mathrm{mSS}$, referent is:

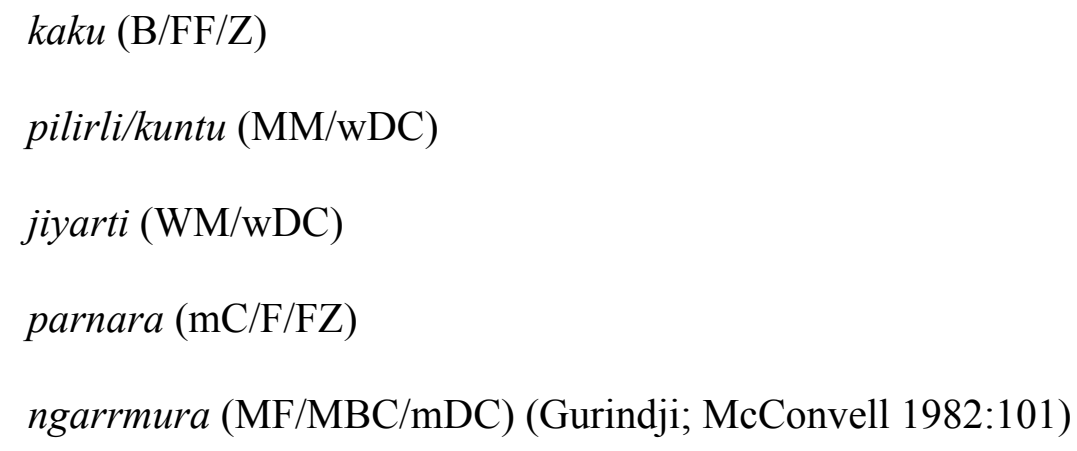

If the referent in Gurindji is dual or plural a number marker is added (McConvell 1982:100). Where the reference point is the speaker's wife's mother all other kin categories are encoded as referent, but the set is incomplete for other categories as reference point. Trirelational terms are extraordinarily elaborate in Bininy Kunwok (northern Australia) (Garde 2008), and seem to have developed where it is inappropriate to refer directly to relatives with whom the speaker or addressee has an avoidance relation. Trirelational kin terms are also found in Gê languages of Central Brazil (Coelho de Souza 2012:208).

Certain complex kin terms in Telefol (PNG) refer to pairs and groups of kin (21). Dual terms in Gooniyandi (Western Australia) designate pairs of individuals by means of the dual postposition yooroo (McGregor 1996:221) (22). Ternary dyadic terms in Gooniyandi 
indicate relations between two referents, and between these and the speaker (23a-b) (McGregor 1996:224).

úlím 'a man and his child' (pl. ulimal)

mángkál 'three or more persons, one or more of whom is female, being either cognates, or related as cognate's affines' cognate, or as co wives' (Telefol; Healey 1962:19)

(22) jaja-yooroo 'my two mother's mothers' (Gooniyandi; McGregor 1996:224)

(23a) marralangi: a H-W pair, the $\mathrm{W}$ is male Ego's $\mathrm{Z}$, the $\mathrm{H}$ is female Ego's $\mathrm{B}$

(23b) woordoolangi: a H-W pair, the $\mathrm{H}$ is male Ego's B, the W is female Ego's Z

Gooniyandi polyadic terms denote groups of kin relative to the speaker (24) (McGregor 1996:239). Two polyadic terms denote kin relations of one of the referents rather than the speaker (1996:237) (25).

(24) yawoolyilanggailangi all of Ego's 'mothers' and 'fathers,' their siblings and spouses

woordoolanggailangi all of Ego's grandparents, their siblings and spouses. 


\section{(25) \\ marnilangilangi a male and all his siblings \\ ngaliganyilangigalangi a female and all her children}

\section{Criteria for the application of first order kin terms}

Speakers need to know the proper use of kin terms and indicators of a connection between propositus and referent. The criteria for the proper use of first order or primary terms (i.e. parent and child terms) draw on narratives about reproduction and nurturance, and about practices such as adoption; primary relatives are co participants in those events. Criteria for affinal relations have to do with performatives such as the key acts in a bestowal or marriage ceremony. Anthropological reports of beliefs about kinship and its foundations (Keen 1985; Godelier 2011; Sahlins 2012) are necessarily based on indigenous narratives, whose forms vary from cryptic accounts of events such as such as 'Britt and Kip have had a baby!' to expanded expositions of beliefs about processes of conception, gestation, birth and nurturance, or of the jural bases of adoption and similar arrangements. In spite of the tradition of structural and cultural accounts of such beliefs (e.g. Schneider 1965; Leach 1966), less has been written about the forms those narratives take, and how they vary, but limitations of space do not permit elaboration of this point.

Some examples of kinship verbs encode birth or procreation. The etymological meaning of the component wulang in the Iwaidja verb 'be mother to' is 'brought out (into the world)' (Evans and Birch 2007:2) (26a). In similar vein, Halpern glosses the Yuma verb 'befather-of' as 'procreate' (Halpern 1942:426) (26b), while Evans (1985) glosses the Kayardild 
expression 'my father' (ngijinmimatharrb) as 'begetter of me', and 'my mother' (ngijinbadiyarrb) as 'carrier of me'.

(26a) ngandu-wula-ng

3A>1sgO-be.mother.to-PP (Iwaidja; Evans and Birch 2007:1)

(26b) * $u$-x'-ami', 'to procreate, to be the father of' (Yuma; Halpern 1942:426)

Criteria for the application of primary kin terms (and indeed affinal terms) vary greatly between cultures. Beliefs about the contribution of the father to conception include the belief that the first man to have intercourse with a woman will be the father of her first child, leading to the seclusion of a bride (among Bahaya of Tanzania), to a belief that multiple acts of copulation are necessary for the development of a foetus, so that more than one man may be recognized as father (Lusi, New Britain) (Moller 1958; Counts and Counts 1983:49; Keen 1985:81). Beliefs encompass extra somatic substances and processes such as the presence of 'grease' (kopong) in semen, mother's milk and foodstuffs (Nebilyer valley PNG, Merlan and Rumsey 1991:42-5), and the cycling of semen from father to son through the medium of tree sap (Kamea PNG; Bamford 2009). In many cultures conception and gestation involve the agency of spirit entities (e.g. Godelier \& Panoff 1998: xvii-xviii).

It is not only the male role that varies. As Strathern (1988:311) remarks, it is not always obvious that "women make babies". Unwed mothers in central Sulawesi receive no social recognition of their motherhood role, and the common usage of a teknonym (mamax, 'mother of $x$ ') is symbolically denied them (Schrauwers 1999:314-5). Baatombu people share 
a view that it is better for a child to be raised by someone other than the birth mother (Alber 2003:496).

Practices of feeding and bringing up a child are the bases of enduring relationships in Zumbagua (Highland Ecuador) (Weismantal 1995), and kin ties can be created by feeding another person in a variety of societies (Strathern 1973; Meigs 1986 cited in Howell 2009; Carsten 1995; Taylor 2000:319; Sahlins 2012:6). Breast feeding is the sign of the mother child bond in Bastar, India (Gregory 2012:193), established also by suckling in Qatar (E1 Guindi 2012). The blood of kinship may be shared through the consumption of the same food as well as through sex, as among Wari' people (Amazonia) (Vilaça 2002, Lepri 2005:715). Among Korowai people a newborn infant is regarded as having no relatives, but gradually acquires them through social interaction (Stasch 2009:112). Not only is there is much variation within the common theme of reproduction and nurturance, but criteria shift with changing beliefs about reproduction, and changing reproductive technologies such as IVF and surrogacy (Strathern 2011).

The degree to which people of the Arctic are bound by criteria of reproduction and nurturance is a matter of some dispute (Nutall 2000:37). Greenlanders exercise a fair degree of choice in converting non kin into kin and in deactivating kin relations. Kin relationships through conception and birth including parents and children, siblings, grandparents and grandchildren, however, appear to be immune to such changes. Kinship through the inheritance of names and associated souls of the dead complement these relations (Nutall 2000:44; cf. Sahlins 2012:9). Iñupiat people privilege the process of parenting over begetting and bearing (Bodenhorn 2000:139). The strongly optative component of Inupiat kinship affiliation stands in stark contrast to the agnatic ideology of Karembola people of 
Madagascar where people are 'completely taken up with proving their intrinsic kind', and people claim to be agnates 'way back from the beginning, from the very root' (hatra hatra, boak'añe, boak am-poto añe) (Middleton 2000:113).

Processes such as marriage and adoption as the bases of relations differ in that they involve the enactment of performatives with the intention of transforming relations. Being a "husband" or an adoptive parent or child is the normative outcome of a procedure enacted for that purpose. There is also a performative aspect of creating parenthood through feeding a child: a Zumbagua man who was adopting a son explained, 'I am going to be his father... Aren't I feeding him right now?' (Weismantel 1995:690).

Adoptive relations tend to be linguistically marked, by the addition to the appropriate kin term of a suffix or other modifier for example, such as adopted in English. In Greenland the suffixes -piaq ('one's own') and -siaq ('borrowed,' 'found') distinguish kin through conception and birth from 'fictive' kin (Nutall 2000:46; see also Guemple 1965 on Inuit, Feinberg 2004:113 on Anuta). Such markers tend to be omitted in the presence of the adoptive relative or in the case of long established relationships.

\section{Criteria for higher order kin terms}

People state the criteria for applying higher order terms as relative product definitions of relations between relations. These can be expressed as simple equivalence statements such as one's mother's or father's sister is one 's aunt (Russell 1950 [1903]; Wallace 1960, 1965; Burling 1965, 1970; Kronenfeld 1980; Keen 1985; Read 2007). The key semantic operation here is substitution of a more concise expression such as grandmother for a longer one - 
parent's mother, or mother's or father's mother. The process of substitution is repeated at several levels or orders (Keen 1985); in English, for example, a man whose mother and father (first order) are the same as one's own is one's brother (second order), one's mother's brother is one's uncle (third order), and one's uncle's daughter is one's cousin (fourth order). This key feature of hierarchical ordering is elided in definitions offered by practitioners of natural language semantics (e.g. Wierzbicka 1992; Goddard 2012).

Relative product definitions arise because people apply categories to the relatives of relatives, through the very project of classifying networks of relations beyond parents and children. Relative product definitions are applied in everyday practical reasoning - my niece recently had a second child, and because I know that in English one's niece's son is one's great nephew I was able correctly to deduce that Jack is my great nephew. Except at the periphery of a terminology kin terms are transitive: the kinsperson of a kinsperson is a kinsperson. Definitions may include alternatives, as in the English definition of aunt as mother's or father's sister or uncle's wife, and of first cousin once removed as first cousin's child or parent's first cousin. The term aunt in the first of these examples may denote different kinds of aunt, one's parent's sister or one's parent's brother's wife. In the second case these first cousins are different relatives under the same category.

The gender and relative age of the propositus, linking relative, and referent may also be salient in relative product definitions. The gender of the propositus is salient in many kinship terminologies, and determines the gender of the referent in the case of terms denoting same-sex or opposite sex siblings (27).

nesese 'older sibling of the same sex' 
nemise 'older sibling of the opposite sex' (Fox; Tax 1955:252)

In Kutenai the terms for siblings' children, grandparents and certain affines differ for male and female propositus (Sapir 1918:415). In the Yolngu and similar terminologies the application of the distinction between male and female propositus results in males and females having the same point of view within kin networks. For example a woman's child and a person's sister's child is their waku, and a man's child and a person's brother's child is their ga:thu. Consequently siblings including opposite sex siblings, and indeed lineage members as a whole, can speak about 'our' waku $(\mathrm{wC} / \mathrm{ZC})$ or 'our' ga:thu $(\mathrm{mC} / \mathrm{BC})$. This is not the case with the Kŭrnai terminology (southeastern Australia) in which lit denotes 'child' or 'same sex sibling's child' for male or female propositus, while bengun denotes 'brother's child' for female propositus (Howitt 1904:169). (Howitt does not record the term for man's sister's child; it may be that bengun denoted 'opposite sex sibling's child'.)

The gender of the linking relative is also salient in, for example, the Yolngu terminology. The child of a man's female child (ga:thu miyalk) is his gaminyarr ( $\mathrm{mDC} / \mathrm{BDC})$ while the child of his son (his ga:thu dirramu) is his marratja (mSC/BSC): here the gender of the linking relative is relevant and explicit. ${ }^{2}$

The relative age between propositus and referent may also be relevant: In Yolngu dialects one's elder brother is one's wa:wa while one's younger brother is one's yokuyuku. The relative age of linking relatives is important in some terminologies of Cape York Peninsula (Australia) such as Umpila, for example, which differentiates the children of FeB and FyB (Thomson 1972). (See also Nayacakalou (1955:48) on 'senior' and 'junior' fathers in Fiji.) Relative age between propositus and referent may over-ride genealogical relationship 
in determining kin term usage. If the referent is younger that the propositus among Mountain Navajo (Hammond and Shepardson 1965:1516), then relations of implied seniority between kin of alternate generations are reversed. If the propositus is older than the MB then $\mathrm{MB}$ (shidá'î) becomes 'sister's son' (shidá') and MZ becomes 'sister's daughter' (shimá yázhî). The categories of other kin reckoned through this connection are shifted accordingly. This relation is expressed in Navajo as 'ata'ashishchíin, 'I am in between', implying born between one's mother and her brother or sister, as the case may be (1965:1517).

The perceived social distance between propositus and referent may also be encoded. For example in the Acoma Keresan kinship terminology n'âya ('mother') has the special vocative form n'ayé used to address one's 'real' mother, which could include a mother's sister to whom one feels particularly close (Miller 1959:182).

\section{$\underline{\text { Substitution }}$}

Rather than a new term being substituted for a string of two or more lower order terms, such as uncle for parent's brother, in many terminologies such strings form higher order expressions (28a-c). Kuwaiti Arabic terms from grandparents, however, are monolexic (Yassin 1977:126-8). Compound kin terms in Danish are highly analysable (29), whereas a term such as cousin in English requires a definition to be understood, as does itoko ('cousin') in Japanese (Wallace and Atkins 1969). In multilexic and analysable expressions the relative product structure of kin relational expressions is patent.
(28a) 'ax
'brother'
bint 'daughter' 
bint 'ax brother['s] daughter, 'niece' (Kuwaiti Arabic; Yassin 1977:126-7)

(28b) apça-çocuğu 'father's brother - child' (FBC etc.)

diaza-çocuğu 'mother's sister - child' (MZC etc.) (rural Turkish; Casson 1973:280)

(28c) úk 'his mother' abbr. from oókeén,

úlóob 'elder sister'

úkúloób 'his mother's elder sister'

aaniing his/my father's younger brother, from *aal his father, abbreviated from aaláb, and niing younger brother

aaniing kaleel 'my father's-younger-brother's wife' (Telefol: Healey 1962:17, 22)

(29)

\author{
mor-mor 'mother's mother' \\ far-mor 'father's mother' \\ moster 'mother’s sister' (Danish; Ragnarsdóttir 1999:77)
}

\title{
Boundaries of kinship terminologies
}

The boundaries of kinship terminologies have two aspects: in terms of the limits of semantic productivity, and the range and potential number of people within a person's kin universe. The semantic boundary occurs where no substitute expression such as cousin is available for a relative product expression such as one's wife's cousin's husband (see Casson 1973 and Busch 1974 on rural Turkish). The English system is in principle unbounded in its denotation of "consanguineal" relatives, however, for one can reckon back to a further grandparental 
generation by adding another great, and one may compute the degree of cousin descended from that relative (first, second, third etc., once, twice, three times removed etc.) (Leaf 2012). The second kind of boundary depends both on the form of the terminology and the pragmatics of use.

A degree of performativity in English kinship affects who may be included among relatives, as shown in Jeanette Edwards's interview of a married couple from Lancashire in England (30). In the example, from Malcolm's point of view Frank counts as an uncle as his father's half-brother. Malcolm's status as a relative is ambivalent, however, as "he never .. made himself part of the family", although "he was [a relative] when we were younger" (Edwards and Strathern 2000:155). It is significant in this regard that Frank was a parent's half sibling.

(30) JEANNETTE: And do your parents have brothers and sisters? So do you have aunts and uncles?

MALCOLM: Well, my mother was an only child. Her father had one.

JANE: So we've got one on his side

MALCOLM: And I don't see him. Because he was, he never, in fact, made himself part of the family.

JEANNETTE: This is your uncle?

MALCOLM: He's a half-brother, 'cause me father's mother married again and he never, sort of, made himself part of the family, you know, he didn't - he was invited, for instance, to weddings, to my parents' golden wedding celebrations and he just never came. 
JEANNETTE: So how's he related to you?

MALCOLM: He's my father's half-brother. 'Cause he was - my father's mother married again and had another child. In fact he's called Butterworth, not Griffiths, you see?

JEANNETTE: Right ... do you class him as family?

MALCOLM: Well he was when we were younger. When he was Uncle Frank, year, and we used to go and visit and everything else. But, I think he just - for all I know he may well be dead, you know? - so I think he sort of took himself out of the family sphere by not, you know, communicating sort of thing. (Edwards and Strathern 2000:155)

$\underline{\text { Evidence for relative product definitions }}$

Relative product definitions are not mere analytical constructs, for evidence of their widespread use abounds (31a-k). They are offered spontaneously and can be elicited in inquiries about the meaning of kin terms.

(31a) na n'ba [or] egya n'ba nua

mother's child [or] father's child sibling (Fanti; Kronenfeld 1973)

(31b) na n'nua banyin wofa

mother's male sibling uncle (Fanti; Kronenfeld 1973)

(31c) wofa n'ba ba 
uncle's child

child (skewing definition) (Fanti; Kronenfeld 1973)

(31d) Atyenge anherr-areye is ampe atyenge altyete-kenhe mape IsgDAT HM/ZSW-pl is ZC 1sgDAT mXC-POSS group 'My anherr are my female cross-cousin's children' (Arrernte; Green 1998:22)

(31e) ngunytju-ku kurtu 'mother's sister' ngunytju 'mother' (Ngaanyatjarra; Dousset 2008:267)

(31f)

kurntili-ku yurntalpa/katja

watjirra

'father's sisters child' 'cross-cousin' (Ngaanyatjarra; Dousset 2008:267)

(31g) katja-ku yurntalpa kaparli 'son's daughter' SD (Ngaanyatjarra; Dousset 2008:267)

$(31 \mathrm{~h})$

pam-ngamayrr pam-ngama-nhrr athlam maternal mother-DAT out of 'the mother of my mother' Alpher 1991:170, 342) pam-kemeyrr

$\mathrm{MM} / \mathrm{MMZ}$ 'mother's mother' (Yir Yoront;

(31i) pam-kewrr-mart pam-ngamanhrrathlam pam-warn-mrr brother's daughter mother out of W/WZ 
'the niece $(\mathrm{mD}, \mathrm{wBD})$ of my mother' 'wife' (Yir Yoront; Alpher $1991: 174,588)$

$(31 \mathrm{j})$

pam-mar-walqyamn athlan ngorvm

pam-koponvmvrr

nephew

my out of

$\mathrm{wDC} / \mathrm{ZDC}$

'from my nephew'

'grandchild'

('nephew's sister's child') (Yir Yoront; Alpher 1991:195)

(31k) Definition of itoko ('cousin') in Japanese:

Chichikata hahakata ni yorazu, oya no kyōdai no father's-side mother's-side DAT depend on, parent POS sibling POS

musuko de toshiue no mono, oya no kyōdai no musume son PART older POS person, parent POS sibling POS daughter de toshiue no mono, oya no kyōdai no musuko de toshishita PART older POS person parent POS sibling POS son PART younger

no mono, oya no kyōdai no musume de toshishita POS person parent POS sibling POS daughter PART younger 
'Independent of whether on father's side or mother's side, parent's sibling's son whether older or younger than oneself, or daughter, whether older or younger than oneself.' (Japanese; Wallace and Atkins 1969; Keen 1985:69)

Relative product definitions may be implicit in parent's explanations to children, as in the extract of an interview (32). The implication in this example is that Sarah's uncle is her father's brother. Examples of elicited definitions (34a-c) include full definitions of uncle and grandmother.

(32) FAT: I'm I'm Uncle George's baby brother SAR: (makes a noise)

FAT: (a)n(d) Uncle Kenny's baby brother... (American English; Goldfield and Snow 1992:200)

(33a) I: What is an uncle?

S: An uncle is your mother or father's brother. Or a brother-in-law (female 22;2.4)

I: What is a daughter?

S: What is a daughter?... She's the female child of the mother and father (female 21;1.13) (Canadian English; Benson and Anglin 1987:49, 53)

(33b) Q. What's a grandmother?

A. Somebody who's your mother's mother. $(6 ; 3)$ 
Q. What's a son?

A. A son is a father's or mother's boy. $(8 ; 8)$ (Haviland and Clark 1974:38)

(33c) What does kaka mean?

vadlanča bhau (FB)

('father's brother')

What does kaku mean?

vadlančya bhavači baiko (FBW)

('father's brother's wife')

Will you be a mavsi [MZ]? How?

bahininčya mulanči mavsi

('I will be my sister's child's mavsi') (Maharashtra Brahmin girl of 9 years 6 months;

Carter 1984:193)

Relative product definitions, then, are implicit or explicit in conversations, and appear both spontaneously and in answers to questions about the meaning of kin terms, especially in the context of socialisation. Some features of definitions in the examples are unexpected, however. For example 'wife' in Yir Yoront is defined in the Yir Yoront lexicon (Alpher 1991) not as the 'daughter' of 'mother's brother' but the 'brother's daughter' of 'mother' (29i), and wDC/ZDC is defined as 'from my nephew,' implying the ZD of ZS (29j). 


\section{$\underline{\text { Relative products and formal analysis }}$}

The specification of relative product definitions of kin terms has been taken as an alternative to varieties of formal analysis of kinship terminologies (e.g. Burling 1963:73; Kronenfeld 1980), but in reality they are very different kinds of thing. Componential analysis "accounts for" focal meanings of kin terms in terms of semantic features such as LINEAL, COLLATERAL and GENERATION as well as gender (Casson 1973; Romney and D'Andrade 1964; Lounsbury 1964; Scheffler and Lounsbury 1971). This procedure is open to the critique of circularity: concepts such as "generation" depend on the very categories they are supposed to explain (Wierzbicka 1987; Keen 1985). Extension rule analysis was developed to account for the polysemy of kin terms, especially the meaning of non-focal "classificatory" kin terms (e.g. Lounsbury 1956; D’Andrade 1981:183). The relations between focal and non-focal applications of a given category has been also been conceived in terms of prototypes (Kronenfeld 2006). While it provides a useful analytic and comparative tool (see for example McConvell 2012) I have suggested elsewhere (Keen 1985) that depicting the equations of formal analyses as "rules" is misleading, for in effect they comprise generalizing descriptions of characteristics of the forms of terminologies.

I have characterized the relative product definitions offered by speakers of a language as specifications of criteria for the proper application of kin terms. They may well be taken to comprise aspects of the semantics of kin terms, and of course they accord with speakers' intuitions, since they are offered by speakers as explanations of kin categories. They are nevertheless only one aspect of the meaning of kin terms, which may include the particular connotations a given kin category has for a variety of speakers. Kronenfeld (2006:207) 
reports, for example, that Fanti people would be inclined to give a relative product definition as a reason for someone being one's egya, but reference to the role in conception in the case of a focal egya. Behavioural norms, he adds, are most clearly articulated with reference to focal kin of a given category.

\section{The forms of kinship terminologies}

A set of relative product definitions generates the form of a terminology, which is to say the ways in which kin categories are distributed across a person's network of kin (Read 2001, 2007), or "genealogical space" (Chit Hlaing [Lehmann] 2011). Anthropologists from Morgan (1870) and Murdock (1949) to Scheffler (1970) and beyond (e.g. Godelier 2011), have classified terminologies of the world's cultures into a limited number of types. There are three main ways of classifying forms of kinship terminology. The first is with reference to a type case, for example Eskimo, Sudanese, Hawaiian, Iroquois, Dravidian etc. Second, the overall form may be captured by morphological characteristics such as generational (Hawaiian), two-line (Dravidian), and bilateral. Third, they may be classified according to the morphology of a core feature such as the parental terminology: lineal (Eskimo), bifurcate collateral (Arabic), bifurcate merging (Iroquois, Dravidian), and incorporating (Hawaiian). Omaha and Crow skewing have been regarded as 'overlays' rather than types of terminology (e.g. McConvell 2012). In the North American context Trautmann and Barnes (1998:55) reclassify Dravidian, Iroquois and Crow-Omaha as Type A crossness, Type B crossness and unilineal systems.

Forms of terminology are generated by a set of relative product definitions, for lower order definitions govern the distribution of certain categories, and constrain the content and 
scope of higher order ones. Having defined aunt and mother's or father's sister and uncle as mother's or father's brother, for example, the range of kin encompassed by cousin, defined as aunt's or uncle's child, is constrained by the distribution of aunt and uncle categories across the network of kin. If one's mother's sister also counted as one's mother and father's brother as one's father, then the range of aunt and uncle would be more restricted. Read $(1984,2001,2007)$ demonstrates in detail how particular terminological forms arise from the definitions that constitute them (see also Leaf 2007). These forms are important where practices depend on the distribution of categories across a social network. In systems of prescriptive marriage, for example, terminologies map categories on to social groups and categories, and in combination with lineage and moiety identity, shape the distribution of potential spouses (see for example Keen 1982 on Yolngu marriage). ${ }^{5}$

\section{Visual and spatial representations of kin networks}

Kin relations are constituted not only through language but also through other semiotic media. The mapping of relational categories on to specific individuals is mediated through cognitive models composed of person tokens and relations. (See Read 2001:258 on the mapping of a system of kinship symbols on to persons.) Cognitive schemas (Strauss and Quinn 1997) or models of kin relations may be represented spatially and as visual representations, which include both graphic representations and transient spatial representations created through gesture (Conklin 1969 [1964]; Dousset 2003; Enfield 2005; cf. Goodwin 2000). McGuinness (1986) hypothesizes that effective representation of kin in spatial arrays is realized through a mapping and processing relationship implemented by a 
"mental step." Mental inferences about the relationships are "mimicked by mentally stepping through the arrays" (1986:278).

Some representations, indicated through gesture as points in space or drawn as points or circles, represent person tokens each associated with one or more kin terms; lines or spaces between points represent the relationships between them. Any two points denote a reciprocal relationship such as grandfather-grandchild, and since the person token represented by a point or circle participates in several reciprocal relationships, each point may be the locus of several kin categories. A visual representation is intimately allied to a discursive one, for each point is labelled relative to others in the array, and once the array is established further relationships across it may be calculated.

A drawing by the late Dja:wa, a Yolngu man (Fig. 1) depicts three core matrisequences of the Yolngu kinship terminology (northern Australia) (Keen 1978:105). Each circle represents a kin category, and double lines link the circles in each sequence. Dja:wa began with the grandparental generation in each sequence and drew succeeding generations moving away from his body. He drew the three sequences in parallel, with the six generations lined up across the sequences consistent with cross cutting patrifilial sequences of terms (e.g. MFZ-M-MBD; FZ-Z-mD/BD). Table 2 substitutes kin terms and glosses for the circles.

[Insert Figure 1 approximately here]

[Insert table 2 approximately here (to follow figure 1] 
Models of kin relations are not only represented graphically. Lao speakers spontaneously represent kin relations by means of gestures (Enfield 2005). Points in space indicate kin terms, often arranged in "levels" of the same generation, while horizontal spaces represent sibling or cousin links. In some gestures the height of indicated points represented relative age (the higher, the older) $(2005: 57-8,61)$. The levels can be rotated ninety degrees so the lower generations are more distant from the body than higher ones (2005:59).

[Insert Figure 2 approximately here]

In Enfield's first example (2005:57-8) (Fig. 2) a woman indicates points in space to explain that her father's older brother's daughter is her $\mathrm{paa}_{4}(\mathrm{FeZ})-$ this is in the skewed terminology in which one's 'cousin' is called by a term in the senior generation. Thus an implicit relative product definition ( $\mathrm{F}-\mathrm{eB}-\mathrm{D}=$ ' $\mathrm{FeZ}$ ') is mapped using a virtual diagram indicating sibling and parent-child relations. When calculating series of relations, "speakers follow a linear stepwise path of kin relations ... and enumerate possible referents of a given term" (2005:58). In the most complex visual diagram a speaker included himself, his brother, their children and their sons' children (2005:59) (Fig. 3). This gestural practice in not confined to Laos, as informal observations of my own (English and Australian) friends and relatives confirms.

[Insert Figure 3 approximately here] 
Several kinds of cognitive schemas are interrelated here. One variety is discursive, consisting of kin categories and expressions such as “one's mother's brother is one's uncle"; the other is visual/spatial. The categories may be mapped on to person tokens and the whole linked to a spatial representation, potentially realisable in gesture or graphic form.

\section{Extended kin networks}

In Australian Aboriginal and similar systems a person may be 'someone's mother' because their actual mother refers to and addresses the person as 'sister' (and by definition, one's mother's sister is one's 'mother'), but where the details of the connection are not known. Relative product logic still applies, however, even where a connection is not traced to a common ancestor; if that woman has a daughter then she is one's 'sister' (Keen 2004; Dousset 2012; see also Feil 1978 on a similar Enga practice.) Kin relations may be extended even further where two people who are not knowingly related compute a relationship through a link in common to a third person in what Dousset (2008) calls the "relational triangle." A key condition for extended kin networks of these kinds appears to be a cohesive and relatively endogamous population, enabling the retention of knowledge of more distant kin. A second condition is that kin connections are deemed to continue even where no apical link between propositus and referent is known. This mode of relatedness is genealogically incomplete.

Kin based social categories and groups provide another means of extending the kinship universe. Australian Aboriginal sections, subsections and semi-moieties are systems of proper names (four, eight and four respectively, often with gender specific variants) which 
are related in notional kin relationships (Dousset 2012). Everyone across a region has one of these names; two people can compute a kinship on the basis of the relation between such names. In some societies personal names serve a similar function. !Kung people of the Kalahari extend the kin relationship of a close kinsperson to those bearing the same personal name. If A encounters someone called B they can compute a kin relation on that basis (Lee 1986). In a related way, inherited personal names in a Connemara community (Ireland) index wider kin relations (Lele 2009).

\section{"Metaphorical" kinship}

The use of kin terms to address and refer to people who do not meet criteria of kin relatedness is very widespread (see Freed 1963:86 on varieties of "fictive" kin). Navajo, for example, use a grandparental terms to address a stranger out of politeness (Landar 1962:988). A parent's female friend may be referred to and addressed as aunty in English, and a Catholic priest as father (Agha 2007:363). In Kuwaiti Arabic yuba ('father') is used between people of equal or ambiguous relative status (34a); a woman may even address her brother as 'father'. These kinds of usage draw on certain criteria for kin terms such as gender, and some connotations of kin terms such as "older than Ego" in the case of aunty, and respect relations in the use of 'father' in Arabic (34b-c). In such cases relative product logic does not apply. The child of someone whom I called aunty in virtue of her friendship with my parents was not my cousin.

(34a) laa, yuba, laa, rayli gariib, wi maa ywaafig 
'No father, my husband is a stranger [not a blood relative], and will not agree...' (Yassin 1977:131)

(34a) ya xaalid ya 'axuuy

VOC Khalid VOC my brother

'Khalid, my brother!' (Kuwaiti Arabic; Yassin 1977:130)

(34b) yuba ihajji

father title

older male relative or close acquaintance (Yassin 1977:130)

Metaphorical kinship may extend to relations between persons and gods. In Nez Perce distinct forms of 'my father' denote one's own father and the Christian God. The periphrastic expression is used for the latter, in which an independent pronoun is combined with the referential form for 'father' (35) (Aoki 1966:357). As we have seen (5c), kin relations in Aboriginal Australia extend to totemic ancestors and the "countries" with which they are associated.

(35) na’tót

1POS-father

'my father'

'ínim píst 
1POS father-REF

'my Father' (Nez Perce; Aoki 1966:357)

\section{Context and the changing ground of kin relations}

Context is often important in the use of kin-relational expressions. Alternative terminologies may be used in the same society, depending on context. Omaha and Crow skewing rules create alternatives of particular kinds (Kronenfeld 2009; McConvell 2009). Ngaanyatjarra people of the Australian Western Desert have three kinship terminologies, in Dousset's view (2012:268-70). The first comes close that the systems described by Elkin, in which cross cousins who are too close to be affines are reclassified as siblings. Second is the system in which parallel-cross neutralization applies to kin in all generations. This is used in ritual contexts where generation moieties are especially salient. In the third system, invoked in marriage negotiations, certain father's sisters (kurntili) are renamed WM (yumari) and certain mother's brothers (kamuru) are reclassified as WF (kaputju). Marriageable cross cousins are distinguished from siblings/parrallel cousins, and from non-marriageable cross cousins, according to genealogical and social/spatial distance.

Context accounts for some apparently systemic features of the Ngarinyin kinship terminology (Kimberley district, northwestern Australia) (Rumsey 1981). People sometimes used the term ngaji ('mother') in the plural to refer to all members of the opposite moiety, including spouses (1981:183). Context of discourse also accounted for what AP Elkin (1964) took to be generational merging in the mother's father's terminological patriline, where males and females of all generations were referred to as "kandingi" (garndingi) and 
"ngadji" (ngaji). Rumsey found that people of alternate generations including mother's father and mother's father's sister were sometimes called mamingi and not garndingi (MF) and ngaji (MFZ). The main context for generational merging was discourse about inter clan relations. Vocative forms such as baba (the vocative equivalent to mamingi) and garndi (the vocative of garningi), however, were far less likely to be used for the wider scope of reference. Furthermore, plural forms such as garndingarrumbu ('your and my uncles') underwent contextual widening more frequently than singular forms (Rumsey 1981:184-5; see also McGregor (2012) on kinship and context in Gooniyandi).

Kronenfeld (2009:320) found the reasons for the choice between skewed and unskewed kin terms among Fanti people somewhat obscure. Decisions depended partly on the socially defined situation, whether a formal lineage occasion, work or leisure; on the attitude of the propositus toward the referent, whether one of respect, equality or authority; and in part on the nature of non-kinship aspects of the relationship, such as age mates, house mates, instructor-apprentice, or relative strangers.

\section{The changing ground of kin relations}

The ground of kin relations upon which kinship tropes depend is not immutable, and not only on account of births, marriages, divorces, and deaths. In the Arctic a child may take the name of a deceased person, adopt the kinship persona of the deceased, and in some examples change gender assignment until puberty (Pospisil and Laughlin 1963; Damas 1964; Guemple 1965; Bodenhorn 2000). In Greenland these new relations do not replace those arising from birth, but complement them (Nutall 2000). Name giving also changes kin relations among Krahô (Brazil); individuals tend to use the same kin terms for other people as their name 
giver, although people resist changing terms for their own children, siblings and parents (Melatti 1976; Coelho de Souza 2012:210). Among Krahô, naming produced Omaha equivalences in the predominantly Crow terminology (Melatti 1979:72-3). Other reported changes include those of clan identity and primary kinship relations upon marriage, and the conversion of uterine kin into agnates in the Papua New Guinea highlands (Feil 1978).

Choices among alternative kin terms also shift the ground of relatedness. A variety of factors lead to the possibility of choices of kin terms, determined by the particular speech situation. In English Mum or Mummy are often preferred as a mode of address, while Mother may be chosen where a more formal register is appropriate. Relative product definitions generate choices, such as between unskewed and skewed terms (Kronenfeld 1980; Rumsey 1981; McConvell and Alpher 2002). ${ }^{6}$

In the case of dense kinship networks people are often faced with choices about what kind of relative a particular person should count as where the relationship is traced through traced through different links, or because of anomalous marriages in prescriptive marriage systems such as the Gooniyandi one (McGregor 2012:167). Maneo people (Seram, Indonesia) who wish to marry, trace relations in such as way that they are related as non siblings, even though the chance of any two people being counted as siblings through one connection or another is high (Hagen 1999). Choices of kin terms may also arise from institutions such as relations between sections, subsections, semi moieties and clans in Aboriginal Australia (Keen 2004; Dousset 2012).

Clan relations among Tombema Enga are sufficient grounds for a sibling relation independent of antecedent kin relations. Men whose mothers are of the same clan are 'from the same netbag', and count each other as 'brother' even if they are related as father and son 
on other grounds. Two men whose wives are sisters become 'brothers' and may be converted to 'brother-in-law' through marriage (Feil 1978:387-9). In a related way, clan ties among Navajo, especially those bestowed by a person's parents, enable a person to address a stranger as if he or she were a member of the nuclear family (Landar 1962:988).

\section{Constitutive practices}

The discussion of the constitutive role of language in kinship so far has covered the application of categories to persons, the criteria for the proper use of kin terms, and the ways in which kinship categories are mapped on to networks of persons. But the use of language in the enactment of relations may be also said to "constitute" kin relatedness. As Zeitlyn (1993:202) remarks, it is not sufficient to analyse kinship classification in order to understand a kinship system.

Many kinship practices are governed by norms, including the expression of overarching values to do with kin relatedness, such as the "axiom of amity" (Fortes 2006) or "mutuality of being" (Sahlins 2012). Yolngu express the former kind of value in saying that kin should "help one another" (gungga'yunhamirr) (Blakeman 2013). The prohibition of incest has been taken to be a universal type of kinship norm (Lévi-Strauss 1969; Heritier 1999). Among the most definite kinship norms in societies of European origin are those that

apply to parent-child relations. In the legal systems of the United States, for example, [o]rdinarily a parent has the right to the custody and supervision of her child. In addition, a parent has the duty to care for and nurture [his or] her offspring. The child has the right to receive this care and nurture and the obligation to yield to reasonable 
parental guidance and supervision. The state has a duty to preserve family stability by ensuring proper care of children. [http://legal-dictionary.thefreedictionary.com/ Parent+and + Child]

In an interview a married couple of "Alltown" in northeastern England expressed a diffuse obligation toward their relatives (36).

(36) JANE: It's always my belief that we should do our best MALCOLM: Yeah JANE: to make sure that our own MALCOLM: I would say financially and physically, I was going to say when they're ill, you go and look after them, don't you? you know? As far as my mother-in-law's concerned, if she's got any little job she wants doing, she can't do it herself, she usually asks. But it's a reciprocal thing, because if I want my trousers shortening, she shortens them for me. (Edwards and Strathern 2000:154)

In many societies kin relationships entail quite explicit norms about appropriate behavior, including social deference, the obligation to engage in obscene joking, and avoidance. (See for example Murdock (1934) on Haida kinship norms, and Warner (1937) on Yolngu ("Murngin") norms). Certain relations entail the use of specific speech registers, to which I now turn.

Baby talk 
Baby talk is a very widespread speech register, recorded in a wide variety of languages (Solomon 2012:122). It is characterized by high pitch, exaggerated positive affect, slowing of tempo, short syntactically simple sentences, extensive use of repetition, a specialized lexicon, and the use of diminutives and kin terms. Although is it characteristic of speech directed by a parent to an infant child, it is also used by others in a caregiver role (2012:172).

\section{Deference}

In many societies certain norms govern the deictic use of kin terms themselves in order to signal appropriate deference. In the record of a conversation between two Vietnamese children (Sidnell and Shohet 2013) a young girl declines to use the appropriate deferential form anh (eB) to address an older boy, who responds with the use of the hyper deferential bà 'grandmother' - an example of a complex practice of ironic deference. Also in Vietnam, in his interaction with a younger sibling $\mathrm{C}$, even a five year old child $\mathrm{A}$ is expected to refer to his younger sibling B, who is C's elder sibling, as anh ('elder brother'). C, by contrast, is not supposed to make third party references from his elder sibling's perspectives. That is to say, A takes C's perspective when referring to B, but C may not take A's perspective (Luong 1990:57; Sidnell and Shohet 2013:620). Kin terms are also used between non kin; the form anh $(\mathrm{eB})$, for example, is used by a man to address a more senior male. Where relative age and status is indeterminate both parties to an interaction may use anh (Sidnell and Shohet 2013:619).

Kin relations in Thailand are also treated as hierarchical (Howard 2007). Social hierarchy is conceived as a relation of mutual dependency in which "the generosity, protection, and compassion of the superior are reciprocated by the services of the 
subordinate" (2007:207). Among children's peer groups in Thailand, however, the use of status neutral and reciprocal forms of person reference and address is pervasive.

Nevertheless, when seeking compliance from a younger child or beneficence from an older, children often invoke the eSb/ySb relationship through the use of kin terms phii/nəoy, evoking mutual dependence, love and respect (2007:205).

The preference in Vietnam for deferential kin terms as modes of address both between kin and non kin, and avoidance of personal pronouns, leads to the use of kin terms from multiple perspectives (Sidnell and Shohet 2013; Luong 1990; Agha 2005:8). In an example of complex social deixis, the term 'mother' may be used to refer to the addressee, the speaker (in self reference), or a non speech act participant in a variety of permutations (Agha 2007:355). In a related usage in English a mother would say to a child "Let mummy do it," referring to herself as "mummy" rather than "me," or her husband would say to the child "Give it to mummy", referring to his wife (see also Merlan 1982:126 on altercentric usages in Mangarrayi).

\section{Civility, joking and avoidance}

Kalapalo speakers (Central Brazil) use a civility register among family members both within households and across language boundaries. In performing the register people enact "expected acts of politeness" between husband and wife, parents and children, and affines (Basso 2007:162). Grammatical elements and name avoidance combine with special lexemes and styles of self presentation such as self abnegation $(2007: 165,169)$. People avoid the use of personal names, speech, and eye contact between spouse's parent and child's spouse, and practise triadic communication (2007:165). The affinal kin term for spouse's parent 
(ifotisofo) is never used in the civility register (2007:170). Also characteristic of the civility register is the use of kin terms to refer to affines: a man refers to his wife as his "sister," his daughter's husband as his "younger brother," and his sister's husband as her "brother." These substitutions are extended to people of other communities including non affines (2007:167). Descriptive nominals are substituted for "husband" and "wife" when uttered by a senior affine to a junior. For example a potential daughter's husband performing bride service is "the one who is cared for"; a young wife is "the one who fans your fire." (p.169). (See also Mandelbaum (2003) on deference behavior among women of north India.) Kutenai people used a variety of grammatical forms in addressing different kinds of kin. Those in the relation of opposite sex sibling or cousin never addressed each other in the second person, but in an oblique form of the third person (Boas 1919:99).

Formalized modes of kinship behavior include joking and avoidance behavior, which also involve special speech registers (for example Radcliffe-Brown 1952; Eggan 1955; Haviland 1979; Rumsey 1982; King 2001). ${ }^{7}$ Among speakers of Kambaata (Highland East Cushitic, Ethiopia), as an aspect of respect behavior (ballishsha) women until recently avoided the names of their husbands' relatives as well as words beginning with the same syllable as an in-law's name. They used a respect vocabulary derived in part from neighbouring languages, including respect forms of pronouns (Treis 2005).

In the past, Guugu-Yimidhirr speakers (Cape York Peninsula, Australia) used a special register when addressing a range of avoidance relations including wife's brother, while a man was not permitted to address his mother-in-law at all (Haviland 1979:369). People described the register as "a bit deep" or "higher," and the style as being "soft/slow" (dani-manaarnaya). A man spoke "sideways" (diiliyirrgaalga) or "crosswise" 
(wurriinyirrgaalga) as opposed to "straight" (dhumbuurgu), not facing his interlocutor directly, and speaking through an intermediary such as his wife in relation to his wife's mother (1979:369). Other relations, such as FF-mSC, were subject to laughter and joking (1979:375).

The avoidance register often substituted a single word for certain common everyday words, and had no equivalent for others (Haviland 1979). Words without respectful equivalents had to be pronounced softly and slowly (Haviland 1979:370). As "forbidden words" (guugu dhabul), words for body parts and activities with sexual associations had no equivalents and could not be used when speaking in the presence of a mother-in-law (1979:373). Everyday pronouns, particles, and derivational formations were permitted $(1979: 368){ }^{8}$

Typically the respect register applied to the people who were involved in the bestowal on a man as a wife, and relatives of the same categories, but the requirements softened with kinship distance (Haviland 1979:378-9). Conversely, obscene joking was practiced between FF-mSS and MF-MDS. This included stylized taunts such as wabala-manaayi, ('be wide,' i.e. 'spread your legs') and bin.ga nala ('open your legs') (1979:382). (See also King (2001) on Dhimal joking and avoidance.)

Avoidance relations may lead to the use of referential kin terms rather than personal names. In light of behavioral constraints between brother and sister, and close opposite sex cross cousins among Murriny-Patha (northern Australia) (Blythe 2010b:462), kinship triangulation is the preferred form of circumspection, and serves to disambiguate reference where each person has several or many relatives of a particular kinship category (2010b:462). Living in a community composed of intermarrying groups, and in which an individual is 
related in some way to all or most of the people in their social universe, Murriny-Patha people routinely link a person referred to by other participants in a conversation to themselves with an utterance such as, "So and so is my such and such kinsperson" (Blythe 2010b). This triangulation of kin relations among participants and non participants presupposes common knowledge of the ground of kin relations between speaker, addressee, propositus and referent.

A section of Murriny-Patha conversation (Blythe 2010b:463-4) (37) illustrates avoidance of the name of a cross cousin, the practice of associating a person who is the topic of conversation with oneself, and the triangulation of kin relations from several perspectives. It also illustrates elided progeny ('my aunt's'), avoidance of one's cousin's name, and the use of a personal name by someone who was not in an avoidance relation.

\author{
(37) Mary me-nge dha-wa \\ 3sS.say.PstIMP-3SIO-PST-EMPH \\ ' $[\mathrm{He}] /$ she was saying to her.'
}

Eliz me-nge dha-pirri

3sS.say.PSTIMP-3sIO-Pst $=3$ sS.stand.PstIMP

'[He]/she was saying to her...'

nukunu-gathu Tjarriwurdi= niyurnu-ya

3SM-FoC woman's name $=3 \mathrm{SFPOS}-\mathrm{PART}$

'It was him [who was saying it], Tjarriwurdi's son.' 


\author{
Mary menge-dha nukunu-gathu-ya $[$ pipin=ngay $]=n i g u r n u ;=$ \\ 3sS.say.PstImP-3sIO-Pst 3sm-Foc-Dub $\quad[\mathrm{fa} . \mathrm{zi}=1 \mathrm{sPos}]=3 \mathrm{sFPos}$ \\ 'It was him who was saying it, my aunt's [son].' \\ pugarli-ngay nyini-ya \\ cousin $=1 \mathrm{sPOS} \quad$ ANAPH-DUB \\ 'That one [is] my cousin [pugarli].'
}

Eliz Kandilmun-ya

woman's name- DuB

'Kandilmun (woman's name),'

Felix yeah yeah be- berenguny tje ngandjin = ngem mam repairable OK ear $1 \mathrm{sS}$.have.NFUT $=3 \mathrm{sS} / \mathrm{say} . \mathrm{NFU}$ 'Yeah yeah, OK OK, I know, he/she said [it].'

nginyipuny-wa $u$ similar - Emph ??

'That's how it was.' (Adapted from Blythe 2010b:463-4)

Registers such as those reviewed here are in part constitutive of kin relationships while signalling that a relationship obtains (Haviland 1979:387). 


\section{Conclusions}

This paper has brought together several aspects of the use of language resources morphosyntactic, semantic, and pragmatic - in the constitution of kin relatedness. To summarize, people map kin relations on to persons by applying kin relational expressions and definitions of kin. To accomplish that they need a kinship lexicon, ways of denoting propositus and referent, modes of indicating a directional (or bi directional) connection between them, and agreed criteria for the application of kin terms. These criteria include narratives of reproduction and nurturance, and relative product definitions of higher order terms. Cognitive models, which can be represented visually in several media, mediate the mapping of kin terms on to persons. These can be very general cultural models of relations between kin categories, as in Dja:wa's drawing, or specific to a particular network, as in the Lao examples. We have seen that a young child's mental map differs from that of an adult; for a young child, kin terms are akin to proper names, so that a man is 'father' to everyone in the family. This usage coincides with and is perhaps reinforced by the tendency toward altercentric kin term usage when speaking to children. ${ }^{9}$ The relational character of kin terms is gradually grasped, so that kin maps become relative to individuals.

Examples of "kinship behavior" include indirect reference, ironic hyper deferentiality, respect registers in avoidance relations, and joking. These are all dependent upon establishing the ground of relations. Kinship lexicons are aspects of social practices, and are used in discourse as linguistic tools. They form somewhat discrete semantic fields, coming under meta categories such as "relatives," and can be invoked in teaching and 
learning about kinship, and drawn upon in practical reasoning. People learn to use kin terms to create cognitive maps of interrelated persons, and to use them in discourse for address, reference and predication. To do this productively one needs to know the criteria for proper application, expressed as narratives and definitions. Not only do people gain competence in the use of kin terms, but they can express the criteria discursively, as when teaching others.

The more complex practices such as indirect reference, trirelational (or triadic) and altercentric terms are dependent upon the established ground of kin relations. "Kinship behaviors" such as the use of respect registers and joking, presuppose and build on the established ground of relations, and are normatively entailed by the relation as constituted by the proper application of kin terms. By the same token, kinship "tropes" (Agha 2007), such as the altercentric uses of kin terms in Vietnamese, rest on shared knowledge of the kinship and affinal network underlying them, at least on the part of adult speakers if not the children to whom they speak.

The ground of kin relations is not static, but is routinely transformed by marriages, births, adoptions, divorces, and deaths. To varying degrees it is relative to the perspective of individuals, and shifts with the perspective of each succeeding generation. It may be open to reinterpretation by the tracing of different links through networks, and ancestral relations are especially prone to cultural amnesia, merging and foreshortening. Such shifts may alter relations among the living, through the merging of collateral ancestors for example. Kinship may be reassigned in some societies, such as through Inuit naming systems. Such reassignment is a second order practice, but with long term effects on subsequent first order practices. 
Positing the constitutive role of language is not to be a linguistic reductionist, for language use interacts with other processes and modes of behavior. We label people on the basis of their perceived participation in events of reproduction and nurturance which, while shaped by language use are in part independent of language. We guide action through such categories and related rules.

Kinship institutions articulate, of course, with others such as descent group organisation, inheritance of possessions, class, caste, marriage practices and networks, and so on. Furthermore, kinship articulates with cosmology not only through conception beliefs but in the kin relations with and between totemic ancestors, country and sacred things in Australia, although space does not allow an exploration of the language usages that make these links.

To return to kinship as an essentially contested concept in anthropology, the above data and discussion have some implications for the character of kinship across cultures. It is evident that the basic semantic structure, in which propositus and referent are identified and a connection between them denoted, is general, albeit expressed by means of a variety of linguistic means from juxtaposition to case-marking. Even though kinship cannot be reduced to "biology" (Sahlins 2012), we find family resemblances between the criteria for the use of kin relational expressions and the beliefs that inform them, centered around themes of reproduction and nurturance. While kinship lexicons vary in content and form, a relative product structure appears to be universal, for everywhere people map relations between relations. It is this transitive structure of kin-relational categories that marks them out from other social fields. 


\section{Endnotes}

\section{$\underline{\text { Acknowledgements }}$}

Earlier versions of this paper were presented at the joint Anthropology Seminar at the Australian National University in May 2012, and at the American Anthropological Association meetings in November 2012. I thank participants for their comments and suggestions. Particular thanks are due to Nicholas Evans, Alan Rumsey and Rupert Stasch for reading and commenting on earlier drafts, and to Peter Whiteley and an anonymous referee for insightful comments and suggestions. I am grateful also to Nicholas Enfield and Current Anthropology for permission to reproduce the images in Figures 1 and 2.

${ }^{1}$ The most common anthropological convention for the propositus is "ego"; this term is misleading, however, since ego is not always the propositus, as in expressions such as "your mother."

${ }^{2}$ See Voget (1953) on the implications of the gender of the linking relative for sibling merging.

${ }^{3}$ Dousset (2008:267) writes that kamuru (MB) is rarely defined as 'mother's brother,' although it does appear in expressions such as kamuru-ku yurntalpa ('mother's brother's daughter') who may be a man's wife (kurri). Some terms, such as kurri ('wife') do not appear in unelicited relative product definitions, and watjirra ('cross cousin') is rarely used in this context.

${ }^{4}$ I do not think "primary genealogical space" (Chit Hlaing 2011) is independent of the "kin term system", such that one maps on to the other. The "genealogical space" is constituted by the application of the speakers' kinship categories. To be sure, a complex relation such as 
great aunt-great nephew can be construed in terms of parent-child links, but these are again constituted through the language, beliefs and conventions of speakers. Respondents of researchers such as AW Howitt, however, had difficulty in construing a kin type such as "my father's father's sister's son's daughter" when applying a modification of Morgan's schedule in southeast Australia. Howitt and his Kŭrnai informant Tulaba devised a system of sticks to represent particular kinspersons (McConvell and Garner 2013:11).

${ }^{5}$ On the relation between the form of terminology and cross cousin marriage in North America see for example Strong (1929); Trautmann and Barnes (1998).

${ }^{6}$ Rumsey (1981) treats the Ngarinyin case as a matter of generation merging rather than skewing.

${ }^{7}$ See also Stasch (2002) on a Korowai naming relationship that incorporates both joking and avoidance.

${ }^{8}$ The respect register included a reduced kinship vocabulary, preserving the distinction between parallel and cross kin in the parents' generation, one's own generation, and the grandchild's generation, but merging them in generations +2 and -1 (Haviland 1979:384).

${ }^{9}$ I thank Alan Rumsey for this suggestion.

\section{References}

Agha, Asif

2005 Norm and Trope in Kinship Behavior. Texas Linguistic Forum 49:1-21.

Agha, Asif

2007 Language and Social Relations. Cambridge: Cambridge University Press. 
Alber E.

2003 Denying Biological Parenthood: Fosterage in Northern Benin. Ethnos 68(4):487506.

Alpher, Barry

1982 Dalabon Dual-subject Prefixes, Kinship Categories, and Generation Skewing. In Heath et al. (eds.) pp.19-30.

Alpher, Barry

1991 Yir-Yoront Lexicon: Sketch and Directory of an Australian Language. Berlin: Mouton de Gruyter.

Anggoro, Florencia K., Dedre Gentner, \& Raquel S. Klibanoff

2005 How to Go from Nest to Home: Children's Learning of Abstract Relational Categories. Proceedings of the 27th meeting of the Cognitive Science Society.

Aoki, Haruo

1966 Nez Perce and Proto-Sahaptian Kinship Terms. International Journal of American Linguistics 32(4):357-68.

Bamberger, Joan

2009 What We Talk About When We Talk About Kinship. Anthropological Quarterly 82(4):1043-48.

Bamford, Sandra

2009 "Family trees" Among the Kamea of Papua New Guinea: A Non-Genealogical Approach to Imagining Relatedness. In Kinship and Beyond: The Genealogical Model Reconsidered, edited by Sandra Bamford and James Leach. New York: Berghahn Books. Pp. 159-74. 
Barry, Laurent S.

1998 Les Modes de Compositions de l'Alliance: Le "Mariage l'Arabe." L'Homme 147:17-50.

Barry, Laurent S.

2000 L'Union Endogame en Afrique et à Madagascar. L'Homme 154/155:67-100.

Basso, Ellen B.

2007 The Kalapalo Affinal Civility Register. Journal of Linguistic Anthropology 17(2):161-83.

Benschop, Marjolein

2002 Rights and Reality: Are Women’s Equal Rights to Land, Housing and Property Implemented in East Africa? Nairobi: United Nations Human Settlements Program.

Benson, Nancy J. and Jeremy M. Anglin

1987 The Child's Knowledge of English Kinship Term. First Language 7(19):41-66. 1987

Blakeman, Bree

2013 An ethnography of emotion and morality: Toward a local Indigenous theory of value and social exchange on the Yolyu Homelands in remote north-east Arnhem Land, Australia. Unpublished doctoral dissertation, School of Archaeology and Anthropology, Australian National University.

Blythe Joe

2010a Kinship Structure vs. Kinterm Usage: A Conversationally Grounded Reassessment of the Murriny Patha Kinship Lexicon. Seminar Paper Presented at Australian National University, 16.3.2010. 
Blythe, Joe

2010b Self-Association in Murriny Patha Talk-in-Interaction. Australian Journal of Linguistics 30(4):447-69.

Boas, Franz

1919 Kinship Terms of the Kutenai Indians. American Anthropologist 21(1):98-101.

Bodenhorn, Barbara

$2000 \mathrm{He}$ Used to be my Relative: Exploring the Bases of Relatedness Among Iñupiat of Northern Alaska. In Cultures of Relatedness: New Approaches to the Study of Kinship. Janet Carsten, ed. Pp.128-48. Cambridge: Cambridge University Press. Boutin, Michael E.

1984 Banggi Kinship Terminology. Anthropological Linguistics 26(3):305-12.

Burling, Robbins

1963 Garo Kinship Terms and the Analysis of Meaning. Ethnology 2(1):70-85.

Burling, Robbins

1965 Burmese kinship terminology. American Anthropologist 67(5):106-17.

Burling, Robbins

1970 American Kinship Terms Once More. Southwestern Journal of Anthropology 26(1):15-24.

Busch, Ruth C.

1974 Over the Bounding Domains: the Limits of Kinship and Kinship Terms in Turkish. Anthropological Linguistics 16(8):415-19.

Busch, Ruth C. 
1980 Reciprocal Kinship Terminology in a Southern Turkish Village. Anthropological Linguistics 22(1):42-45.

Carsten, Janet

1995 The Substance of Kinship and the Heat of the Hearth: Feeding, Personhood, and Relatedness Among Malays in Pulau Langkawi. American Ethnologist 22(2):22341.

2000 (ed.) Cultures of Relatedness: New Approaches to the Study of Kinship. Cambridge: Cambridge University Press.

2004 After Kinship. Cambridge: Cambridge University Press.

Carter, Anthony T.

1984 The Acquisition of Social Deixis: Children's Usages of Kin Terms in Maharashtra, India. Journal of Child Language 11:179-201.

Casson, Ronald W.

1973 Paired Polarity Relations in the Formal Analysis of a Turkish Kinship Terminology. Ethnology 12(3):275-97.

Casson, Ronald W.

1978 On Paired Polarity Relations: a Turkish Kinship Terminology Reconsidered. Anthropological Linguistics 20(8):359-66.

Chen, T.S. and J.K. Shyrock

1932 Chinese Relationship Terms. American Anthropologist 34(4):623-69.

Chit Hlaing, FKL (Lehmann, FK) 
2011 Kinship Theory and Cognitive Theory in Anthropology. In A Companion to Cognitive Anthropology, edited by David B. Kronenfeld, Giovanni Bennardo, Victor C. de Munck, and Michael D. Fischer, pp. 254-69.

Coelho de Souza, Marcela

2012 The Making and Unmaking of "Crow-Omaha" Kinship in Central Brazil(ian Ethnology). In Crow-Omaha: New Light on a Classic Problem of Kinship Analysis. Thomas R. Trautmann and Peter Whiteley ed. Pp. 205-222. Tucson: University of Arizona Press.

Conant, Francis P.

1961 Jarawa Kin Systems of Reference and Address: A Componential Comparison. Anthropological Linguistics 3(2):19-33.

Conklin, Harold C.

1969 (1964). Ethnogenealogical Method. In Cognitive Anthropology. Stephen A. Tyler, ed. Pp. 93-122. New York: Holt, Rinehart and Winston.

Counts, Dorothy Ayers, and David R. Counts 1983 Father's Water Equals Mother's Milk: the Conception of Parentage in Kaliai, West New Guinea. Mankind 14:46-56.

Dahl, Osten and Masja Koptjevskaya-Tamm

2001 Kinship in Grammar. In Dimensions of Possession, edited by Iréne Baron, Michael Herslund and Finn Sørensen, 201-26. Amsterdam: John Benjamins Publishing Company.

Damas, David

1964 The Patterning of the Iglulingmiut Kinship System. Ethnology 3(4):377-88. 
D'Andrade, RG

1981 The Cultural Part of Cognition. Cognitive Science 5(3):179-95.

Dixon, R.M.W.

1989 The Dyirbal kinship system. Oceania 59(4):245-68.

Doumas, Leonidas .A., John E. Hummel, and Catherine M. Sandhofer

2008 A Theory of the Discovery and Predication of Relational Concepts. Psychology Review 115(1):1-43.

Dousset, Laurent

2003 Indigenous Modes of Representing Social Relationships: a Short Critique of the “Genealogical Concept". Aboriginal Studies 2003(1): 19-29.

Dousset, Laurent

2008 The 'Global' Versus the 'Local': Cognitive Processes of Kin Determination in Aboriginal Australia. Oceania 78(3):260-79.

Dousset, Laurent

2012 Australian Aboriginal Kinship: An Introductory Handbook with Particular Emphasis on the Australian Western Desert. Marseilles: PCP Publications. Edwards, Jeannette and Marilyn Strathern

2000 Including our own. In Cultures of Relatedness: New Approaches to the Study of Kinship, edited by Janet Carsten, 149-166. Cambridge: Cambridge University Press.

Eggan, Fred

1955 The Cheyenne and Arapaho kinship system. In Social Anthropology of North American Tribes, edited by Fred Eggan, 35-95. Chicago: The University of Chicago Press. 
El Guindi, Fadwa

2012 Crossing Prohibited Kinship Boundaries in Qatar: an Ethnographic Case. Paper presented at the American Anthropological Association meetings, San Francisco, 15th November 2012.

Elkin, A.P.

1964 The Australian Aborigines. Sydney: Angus and Robertson.

Enfield, Nicholas J.

2005 The Body as Cognitive Artifact in Kinship Representations: Hand Gesture Diagrams by Speakers of Lao. Current Anthropology 46(1):51-73.

Evans, Nicholas D.

1985 Kayardild. Unpublished PhD thesis, Australian National University. 1995 A Grammar of Kayardild with Historical-Comparative Notes on Tangkic. Berlin, New York: Mouton de Gruyter.

Evans, Nicholas and Bruce Birch

2007 Being so Fathered and so Husbanded: Kinship Verbs in Iwaidja. Unpublished paper; DoBeS Workshop, Nijmegen June 14 2007. Electronic document, http://www.mpi.nl/DOBES/meetings/ws07_presentations/Iwaidja.pdf

Everett, Daniel L.

2005 Cultural Constraints on Grammar and Cognition in Pirahã: Another Look at the Design Features of Human Language. Current Anthropology 46:621-46.

Feil, Daryl K.

1978 Straightening the Way: an Enga Kinship Conundrum. Man (n.s.) 13(3):380-401. Feinberg, Richard 2004 
What is Polynesian kinship all about. Ethnology 20(2):115-31.

Feng, HY

1936 Teknonymy as a Formative Factor in the Chinese Kinship System. American Anthropologist 38(1):59-66.

Fortes, Meyer

2006 Kinship and the Social Order: The Legacy of Lewis Henry Morgan. New Brunswick: Transaction Publishers.

Freed, Stanley A.

1963 Fictive Kinship in a North Indian Village. Ethnology 2(1):86-103.

Gaille, WB

1955-6 Essentially contested concepts. Proceedings of the Aristotelian Society 56:16798.

Garde, Murray

2008 Person Reference, Proper Names and Circumspection in Bininj Kunwok Conversation. In Discourse and Grammar in Australian Languages, edited by Ilana Mushin and Brett Joseph Baker, 203-32. Amsterdam: John Benjamins Publishing Company.

Garth, Thomas R. Jr

1944 Kinship Terminologies, Marriage Practices, and Behavior toward Kin among the Atsugewi. American Anthropologist 46(3):348-61.

Garvin, Paul L.

1951 Kutenai IV: Word Classes. International Journal of American Linguistics 17(2):8497. 
Gentner, Dedre and Kenneth J. Kurtz

2005 Relational Categories. In Categorization Inside and Outside the Laboratory: Essays in Honor of Douglas L. Medin, edited by Woo-Kyoung Ahn, Robert L. Goldstone, Bradley C. Love, Arthur B. Markman \& Phillip Wolff, 151-75,. Washington DC: APA.

Goddard, Cliff

2012 Semantic Primes, Semantic Molecules, Semantic Templates: Key Concepts in the NSM Approach to Lexical Typology. Linguistics 50(3):711-43.

Godelier, Maurice

2011 The Metamorphoses of Kinship. London, New York: Verso Books.

Godelier, Maurice and M. Panoff

1998 Introduction. In La production du corps: Approaches anthropologiques et historiques. M. Godelier \& M. Panoff, eds. Pp. xi-xxv. Amsterdam: Éditions des archives contemporaines.

Goldfield, Beverly A. and Catherine E. Snow

1992 ‘What's your Cousin Arthur's Mommy’s Name?': Features of Family Talk about Kin and Kin terms. First Language 12:187-205.

Goodwin, Charles

2000 Action and Embodiment Within Situated Human Interaction. Journal of Pragmatics $32: 1489-1522$.

Green, Jenny

1998 Kin and Country: Aspects of the Use of Kinterms in Arandic Languages. Unpublished Masters dissertation, University of Melbourne. 
Gregory, Chris

2012 Skinship: Touchability as a Virtue in East-Central India. Hau: Journal of Ethnographic Theory 1(1):179-209.

Guemple, D. L.

1965 Saunik: Name-Sharing as a Factor Governing Eskimo Kinship Terms. Ethnology $4(3): 323-35$.

Hagen, James M.

1999 Reckoning Kinship in Maneo (Seram, Indonesia). American Ethnologist 26(1):173-95.

Hale, Kenneth

1966 Kinship Reflections in Syntax: Some Australian Languages. Word 22:318-24. Halpern, Abraham M.

1942 Yuma Kinship Terms. American Anthropologist (N.S.) 44:425-41.

Hammond, Blodwen and Mary Shepardson

1965 The Born-Between Phenomenon among the Navajo. American Anthropologist 67(6):1516-17.

Haviland, John

1979 Guugu-Yimidhirr Brother-in-Law Language. Language in Society 8(3):365-93.

Haviland, Susan E. and Eve V. Clark

1974 'This Man's Father is my Father's Son': a Study of the Acquisition of English Kin Terms. Journal of Child Language 1:32-47.

Healey, Alan 
1962 Linguistic Aspects of Telefomin Kinship Terminology. Anthropological Linguistics 24(7):14-28.

Heath, Jeffrey, Francesca Merlan and Alan Rumsey (eds.) 1982 Languages of Kinship in Australia. (Oceania Linguistic Monographs No. 24.) Sydney: University of Sydney.

Henderson, J. and V. Dobsib

1994 Eastern and Central Arrernte to English Dictionary. Alice Springs: Institute for Aboriginal Development Press.

Héritier, Françoise 1999

Two Sisters and their Mother. Cambridge MA: The MIT Press.

Howard, Kathryn

2007 Kinterm usage and Hierarchy in Thai Children's Peer Groups. Journal of Linguistic Anthropology 17(2):204-30.

Howell, Signe

2009 Adoption of the Unrelated Child: Some Challenges to the Anthropological Study of Kinship. Annual Review of Anthropology 38:149-66.

Howitt, AW

1904 Native Tribes of South-East Australia. London: MacMillan.

Ives, John W.

1998 Developmental Porcesses in the Pre-Contact History of Athapaskan. In

Transformations of Kinship, edited by Maurice Godelier, Thomas R. Trautmann and Franklin E. Tjon Sei Fat, 95-139. Washington and London: Smithsonian Institution Press. 
Jacobs, Melville

1932 Northern Sahaptin Kinship Terms. American Anthropologist 34(4):688-93.

Jonsson, Niklas

2001 Kin Terms in Grammar. In Language Typology and Language Universals: An International Handbook, edited by Martin Haspelmath, Ekkehard König, Wulf Oesterreicher and Wolfgang Raible, 1203-14. Berlin, New York: Walter de Gruyter. Kay, Paul

1975 The Generative Analysis of Kinship Semantics: A Reanalysis of the Seneca Data.

Foundations of Language 13(2):201-14.

Keen, Ian

1978 One Ceremony, One Song: An Economy of Religious Knowledge Among the Yolngu of Northeast Arnhem Land. PhD Dissertation, Australian National University.

Keen, Ian

1982 How Some Murngin Men Marry Ten Wives, or the Marital Implications of Matrilateral Cross-Cousin Structures. Man (N.S.) 17(4):620-42.

Keen, Ian

1985 Definitions of Kin. Journal of Anthropological Research 41:62-90.

Keen, Ian

2004 Aboriginal Economy and Society: Australia at the Threshold of Colonisation. Melbourne: Oxford University Press.

Keen, Ian

2013 The Language of Possession: Three Case Studies. Language in Society 
King, J.T.

2001 The Affinal Kin Register in Dhimal. Linguistics of the Tibeto-Burman Area 24(1):163-66.

Koch, Harold

1982 Kinship Categories in Kaytej Pronouns. In Heath et al. (eds.) pp.64-71.

Kockelman, Paul

2007 Inalienable Possession and Personhood in a Q’eqchi’ Mayan Community. Language in Society 36:343-69.

Kronenfeld, David

1973 Fanti Kinship: the Structure of Terminology and Behavior. American Anthropologist 75(5):1577-95.

Kronenfeld, David

1980 Particularistic or Universalistic Analyses of Fanti Kin-Terminology: the Alternative Goals of Terminological Analysis. Man (n.s.)15:151-69.

Kronenfeld, David

2001 Morgan, Trautmann and Barnes, and the Iroquois-type Cross/Parallel Distinction. Anthropos 96(2):423-432.

Kronenfeld, David

2006 Issues in the Classification of Kinship Terminologies: Toward a New Typology. Anthropos 101(1):203-19.

\section{Kronenfeld, David}

2009 Fanti Kinship and the Analysis of Kinship Terminologies. Urbana and Chicago: University of Illinois Press. 
Landar, Herbert

1962 Fluctuations of Forms in Navaho Kinship Terminology. American Anthropologist 64:985-1000.

Laughren, Mary

1982 Warlpiri Kinship Structure. In Heath et al. (eds.) pp. 72-85.

Leach, Edmund

1966 Virgin Birth. Proceedings of the Royal Anthropological Institute 1966:39-49.

Leaf, Murray J.

2007 Empirical Formalism. Structure and Dynamics 2(1):5-23.

Leaf, Murray J.

2012 Kinship Boundaries and Pluralism. Paper delivered at the American Anthropological Association Meetings, San Francisco, 17th November 2012.

Lee, Richard.

1986 !Kung Kin Terms, the Name Relationship and the Process of Discovery. In The Past and Future of !Kung Ethnography: Critical Reflections and Symbolic Perspectives: Essays in Honour of Lorna Marshall, edited by Megan Biesele, Robert Gordon \& Richard Lee. Hamburg: Helmut Buske Verlag. Pp.77-102.

Lele, Veerenda

2009 "It's not really a nickname, it's a method": Local Nicknames, State Inmates, and Kinship Register in the Irish Gaeltacht. Journal of Linguistic Anthropology 19(1)116.

Lepri, Isabella 
2005 The Meaning of Kinship Among the Ese-Ejja of Northern Bolivia. Journal of the Royal Anthropological Institute 11:703-24.

Levinson, Steve

2007 Optimizing person reference: perspectives from usage on Rossel Island. In Person Reference in Interaction: Linguistic, Cultural, and Social perspectives, edited by N. Enfield and T. Stivers, 9-72. Cambridge: Cambridge University Press.

Levinson, Steve

2010 Advancing Our Grasp of Constrained Variation in a Crucial Cognitive Domain. Behavioral and Brain Sciences 33:391-2.

Lévi-Strauss, Claude

1969 The Elementary Structures of Kinship. London: Eyre and Spottiswoode. Lounsbury, Floyd G.

1956 A Semantic Analysis of the Pawnee Kinship Usage. Language 32(1):158-194. Lounsbury, Floyd G.

1964 The Structural Analysis of Kinship Semantics. In Proceedings of the Ninth International Congress of Linguists, edited by HG Hunter, 1073-93. The Hague: Mouton.

Luong, Hy Van

1990 Discursive Reference and Linguistic Meanings: The Vietnamese System of Person Reference. Amsterdam: John Benjamins Publishing Company.

Mandelbaum, David Goodan

2003 Women's Seclusion and Men’s Honor: Sex Roles in North India, Bangladesh and Pakistan. Tuscon: University of Arizona Press. 
Matthews, GH

1959 Proto-Siouan Kinship Terminology. American Anthropologist 61(2):252-78.

Mattina, Anthony and Clara Jack

1992 Okanagan-Collville Kinship Terms. Anthropological Linguistics 1(4):117-37.

McCallum, Cecilia

1990 Language, Kinship and Politics in Amazonia. Journal of the Royal Anthropological Institute 25(3):412-33.

McConvell, Patrick

1982 Neutralisation and Degrees of Respect in Gurindji. In Heath et al. (eds.) pp. 86106.

McConvell, Patrick

2012 Omaha Skewing in Australia: Overlays, Dynamism and Change. In Crow-Omaha: New Light on a Classic Problem in Kinship Analysis, edited by Thomas R. Trautmann and Peter Whiteley, 243-59. Tucson: University of Arizona Press.

McConvell, Patrick and Barry Alpher

2002 On the Omaha trail in Australia: Tracking Skewing from East to West. Anthropological Forum 12(2):159-75.

McConvell, Patrick and Helen Garner

2013 The Descent of Morgan in Australia: Kinship Representation from the Australian Colonies. Structure and Dynamics 6(1):1-23. https://escholarship.org/uc/item/5711t341\#

McConvell, Patrick and Kazuko Obata 
n.d. A Higher Order of Kinship Semantics: Trirelational Kinship Terms and Kinship Pronouns in Australia. Electronic document, http://wiki.pacificcredo.fr/images/6/65/Kobe_poster_final.pdf(accessed 3 April 2012).

McGregor, William

1996 Dyadic and Polyadic Kin Terms in Gooniyandi. Anthropological Linguistics 38(2):216-47.

McGregor, William

2012 Kin Terms and context among the Gooniyandi. Anthropological Linguistics 54(2):161-86.

McGuinness, Carol

1986 Problem Representation: the Effects of Spatial Arrays. Memory and Cognition 14(3): 270-280.

Meigs Anna S.

1986 Blood, kin and food. In Conformity and Conflict: Readings in Cultural Anthropology, edited by James P. Spradley, David W. McCurdy, 117-80. Boston: Little Brown Higher Education.

Melatti, Julio

1976 Nominadores e genitores. Um Aspeto do Dualismo Krahó. In Leituras de Etnologia Brazileira, edited by E. Schaden, pp. 139-48. Sao Paolo: Cia Editora Nacional.

Melatti, Julio

1979 The Relationship System of the Krahó. In Dialectical Societies: the Gé and Bororo of Central Brazil, edited by D. Maybury-Lewis, pp. 46-82. Cambridge MA: Harvard University Press. 
Merlan, Francesca

1982 "Egocentric" and "Altercentric" Usage of Kin Terms in Mangarrayi. In Heath et al. (eds.) pp.125-40.

Merlan, Francesca and Alan Rumsey

$1991 \mathrm{Ku}$ Waru: Language and Segmentary Politics in the Western Nebilyer Valley:

Papua New Guinea. Cambridge: Cambridge University Press.

Mestheneos, Elizabeth and A. Svensson-Dianellon

n.d. Naming grandparents. www.sextant.gr/docs/GrandPKinship_Terminology.doc

Middleton, Karen

2000 How Karembola men become mothers. In Cultures of Relatedness: New

Approaches to the Study of Kinship, edited by Janet Carsten, 104-127.

Miller, Wick R.

1959 Some Notes on Acoma Kinship Terminology. Southwestern Journal of Anthropology 15(2):179-84.

Moller, MSG

1958 Bahaya Customs and Beliefs in Connection with Pregnancy and Childbirth.

Tanganyika Notes and Records. 50:112-17.

Morgan, Lewis Henry

1870 Systems of Consanguinity and Affinity of the Human Family. Washington:

Smithsonian Institution.

Mufwene, Salikoko S.

1985 Some Bantu Ways of Talking: the Case of Kinship Vocabularies. Language

Sciences 7(2):271-282. 
Murdock, George Peter

1934

Murdock, George Peter

1949 Social Structure. New York: Macmillan.

Nayacakalou, Rusiate R.

1955 The Fijian System of Kinship and Marriage. The Journal of the Polynesian Society 64:44-55.

Needham, Rodney

1971 Remarks on the analysis of kinship and marriage. In Rethinking Kinship and Marriage. R. Needham, ed. Pp. 1-34. London: Tavistock.

Nichols, Joanna

1986 Head-marking and dependent-marking grammar. Language 62(1):56-119.

Nutall, Mark

2000 Choosing kin: sharing and subsistence in a Greenlandic hunting community. In

Dividends of Kinship: Meanings and Uses of Social Relatedness. EBSCO

Publishing eBook Collection

Pospisil, Leonard and William S. Laughlin

1963. Kinship Terminology and Kindred Among the Nunamiut Eskimo. Ethnology 2(2):180-9.

Price-Williams, Douglass, Ormond W. Hammond, Ceel Edgerton, and Michael Walker

1977 Kinship Concepts among Rural Hawaiian Children. In Piagetian Psychology: Cross Cultural Contributions. P. Dasen, ed. Pp. 296-334. New York: Gardner Press Inc.

Radcliffe-Brown, Alred R. 
1952 On Joking Relationships. In Structure and Function in Primitive Society.

New York: Free Press. Pp. 90-104.

Ragnarsdóttir, Hrafnhildur, Simonsen, Hanne G. and Kim Plunket

1999 The Acquisition of Past Tense Morphology in Icelandic and Norwegian children:

an experimental study. Journal of Child Language 26(3): 577-618.

Read, Dwight

1984 An Algebraic Account of the American Kinship Terminology. Current Anthropology 25:417-449.

Read, Dwight

2001 Formal Analysis of Kinship Terminologies and its Relationship to What Constitutes Kinship. Anthropological Theory 1(2):239-67.

Read, Dwight

2007 Kinship theory: a Paradigm Shift. Ethnology 46:329-364.

Romney, A. Kimball and Roy G. D'Andrade.

1964. Cognitive Aspects of English Kin Terms. American Anthropologist 66: 3(2). 146-

70.

Rumsey, Alan

1981 Kinship and Context Among the Ngarinyin. Oceania 51(3):181-92.

Rumsey, Alan

1982 Gun-gunma: An Australian Aboriginal Avoidance Language and its Social

Function. In Heath et al. eds. pp.160-81.

Russell, Bertrand

1950 [1903] The Principles of Mathematics. London: Allen and Unwin. 
Sahlins, Marshall D.

1962 Moala: Culture and Nature on a Fijian Island. Ann Arbor: University of Michigan Press.

Sahlins, Marshall

2012 What Kinship Is - And Is Not. Chicago: Chicago University Press.

Sapir, Edward

1918 Kinship Terms of the Kootenay Indians. American Anthropologist 20(4):14-18.

Scheffler, Harold

1970 Systems of kin classification: a structural typology. In Kinship Systems in the Morgan Centennial Year, edited by Priscilla Reining, 113-33. Washington D.C.: Anthropological Society of Washington.

Scheffler, Harold W.

1978 Australian Kin Classification. Cambridge: Cambridge University Press.

Scheffler, Harold W. and Floyd G. Lounsbury

1971 A Study in Structural Semantics: The Siriono Kinship System. Englewood Cliffs, NJ: Prentice-Hall.

Schneider, David

1965 American Kin terms and Terms for Kinsmen: a Critique of Goodenough's Componential Analysis of Yankee Kinship Terminology. American Anthropologist 67(5):288-308.

Schneider, David

1984 A Critique of the Study of Kinship. Ann Arbor: University of Michigan Press. Schrauwers, Albert 
1999 Negotiating Parentage: the Political Economy of 'Kinship' in Central Sulawesi, Indonesia. American Ethnologist 26(2):310-23.

Shapiro, Warren

1981 Miwuyt Marriage: The Cultural Anthropology of Affinity in Northeast Arnhem Land. Philadelphia: Institute for the Study of Human Issues.

Shimkin, DB

1941 The Uto-Aztecan System of Kinship Terminology. American Anthropologist 43(2):223-245.

Sidnell, Jack and Merav Shohet

2013 The problem of Peers in Vietnamese Interaction. Journal of the Royal Anthropological Institute 19(3):618-38.

Solomon, Olga

2012 Rethinking baby talk. In The Handbook of Language Socialization, edited by Allesandro Duranti, Elinor Ochs and Bambi B. Schiefflin,121-49, Chichester: Wiley-Blackwell.

Speck, Frank G.

1918 Kinship Terms and the Family Band among the Northeastern Algonkian. American Anthropologist 20(2):143-61.

Stasch, Rupert

2002 Joking Avoidance: A Korowai Pragmatics of Being Two. American Ethnologist 29(2):335-65.

Stasch, Rupert 
2009 Society of Others: Kinship and Mourning in a West Papuan Place. Berkeley:

University of California Press.

Strathern, Andrew

1973 Kinship, Descent and Locality: Some New Guinea Examples. In The Character of Kinship, edited by Jack Goody, 21-34. Cambridge: Cambridge University Press.

Strathern, Marilyn

1988 The Gender of the Gift: Problems with Women and Problems with Society in Melanesia. Berkeley: University of California Press.

Strathern, Marilyn

2011 What is a Parent? Hau: Journal of Ethnographic Theory 1(1):245-78.

Strauss, Claudia and Naomi Quinn

1997 A Cognitive Theory of Cultural Meaning. Cambridge: Cambridge University Press.

Strong, WD

1929 Cross-Cousin Marriage and the Culture of the Northeastern Algonkian. American Anthropologist 31(2):277-88.

Tax, Sol

1955 Organization of the Fox Indians. In Social Anthropology of North American

Tribes, edited by Fred Eggan, 241-82. Chicago: The University of Chicago Press. Taylor, Anne-Christine

2000 Le Sexe de la Proie: Représentations Jivaro du Lien de Parenté. L’Homme 154155:309-333.

Thomson, Donald 
1972 Kinship and Behaviour in North Queensland. Canberra: Australian Institute of Aboriginal Studies.

Trautmann, Thomas R. and RH Barnes

1998 "Dravidian," "Iroquois," and "Crow-Omaha" in North American Perspective. In Transformations of Kinship, edited by Maurice Godelier, Thomas R. Trautmann and Franklin E. Tjon Sei Fat, 27-58. Washington and London: Smithsonian Institution Press.

Treis, Yvonne

2005 Avoiding their names, avoiding their eyes: how Kambaata women respect their inlaws. Anthropological Linguistics 47(3):292-320.

Trott, Christopher G.

2005 Ilaagit and TuqПuraqtuq Understandings of Kinship and Social Relationships.

Unpublished paper prepared for First Nations, First Thoughts, Centre of Canadian Studies. Native Studies Department, University of Manitoba.

Turner, Terence

2012 Schemas of Kinship Relations and the Construction of Social Categories among the Mebêngôkrê Kayapó. In Crow-Omaha: New Light on a Classic Problem of Kinship Analysis. Thomas R. Trautmann and Peter Whiteley ed. Pp. 223-42. Tucson: University of Arizona Press.

Tyler, Stephen A.

1965 Koya Language Morphology, and Patterns of Kinship Behavior. American Anthropologist 67:1428-1440.

Vilaça, Apericida 
2002 Making Kin Out of Others in Amazonia. Journal of the Royal Anthropological Institute 8:347-65.

Voget, Fred

1953 Kinship changes at Caughnawaga. American Anthropologist 55(3):385-94.

Walker, Harry

2009 Transformations of Urarina Kinship. JASO-online (NS) 1(1):52-69.

Wallace, Anthony F. C.

1960 The Meaning of Kinship Terms. American Anthropologist 62(1):58-80.

Wallace, Anthony F. C.

1965 The Problem of the Psychological Validity of Componential Analysis. American Anthropologist 67(5):229-248.

Wallace, Anthony F. C. \& John Atkins

1969 The Meaning of Kinship Terms. In Cognitive Anthropology. S. Tyler, ed. Pp. 34569. Austin: Holt, Rinehart and Winston.

Warner, W. Lloyd

1937 A Black Civilization: A Social Study of an Australian Tribe. Harper, New York Weismantel, Mary

1995 Making Kin: Kinship Theory and Zumbagua Adoptions. American Ethnologist 22(4):685-704.

Wierzbicka, Anna

1986 Semantics and the Interpretation of Cultures: The Meaning of 'Alternate Generations' Devices in Australian Language. 21(1):34-49.

Wierzbicka, Anna 
1987 Kinship semantics: lexical universals as a key to psychological reality. Anthropological Linguistics 29(2):131-56.

Wierzbicka, Anna

1992 Semantics, Culture, and Cognition: Human Concepts in Culture-Specific Configurations. New York and Oxford: Oxford University Press.

Wilkins, David P.

1993 Linguistic Evidence in Support of a Holistic Approach to Traditional Ecological Knowledge. In Traditional Ecological Knowledge: Wisdom for Sustainable Development, ed. N.M. Williams and G. Baines, 71-93. Canberra: Centre for Resource and Environmental Studies, Australian National University.

Witherspoon, Gary

1975 Navajo Kinship and Marriage. Chicago: University of Chicago Press.

Wittgenstein, Ludwig

1953 Philosophical Investigations. Oxford: Blackwell.

Yassin, M. Aziz F.

1977 Kinship Terms in Kuwaiti Arabic. Anthropological Linguistics 19(3):126-32.

Young, Robert W. and William Morgan

1980 The Navajo Language: A Grammar and Colloquial Dictionary. Albuquerque:

University of New Mexico Press.

Zeitlyn, David

1993 Reconstructing Kinship, or, the Pragmatics of Kin Talk. Man N.S. 28(2):199-224.

Zorc, David 
1986 Yolngu-Matha Dictionary. Electronic document, http://www.ntu.edu.au/yolngustudies/resources.htm\#dict 
Table 1 Means of indicating a connection between propositus and referent

Marking on the head

(a) Head-marking by prefix

shimá my mother

nimá your mother

bimá $\quad$ his/her mother (Navajo; Young and Morgan 1980)

(b) Syllabic nasal prefix

nana n'na grandmother's mother (Fanti; Kronenfeld 1980; Dolphyne 1986:37)

(c) Pronominal prefix

tiwéye wife's brother

'intiwéye my wife's brother (Nez Perce; Aoki p.357)

(d) Prefix with modification of the stem

áataál my FF

kaalábáal your FF

aalábáal his FF (Telefol; Healey 1962:15, 25)

(e) Pronominal suffix

kirda-na 
father-1Sg

“my father" (Warlpiri; Laughren 1982:74)

(f) Clitic possessive pronouns $v$ free pronouns
mamachemi my father
dedasheni your (sg.) mother
chemi da my sister (Georgian; Dahl and Koptjevskaya-Tamm 2001:209)

\section{Dependent marking,}

(g) Grammatical case

ngumban-da wakatha maku kiyarrng-k

2sgPOSS-NOM sisterNOM sister-in-lawNOM two-NOM

"Your sister has two sisters-in-law.” (Kayardild; Evans 1995:318)

dathin-karra maku-karra kularrin-da kurrka-th

that-GEN woman-GEN brother-NOM take-ACT

“That woman's brother took (it)." (Kayardild; Evans 1995)

(h) Clitic

Bill's aunty (English)

(i) Adpositions

oya no $k i$ 
parent POS child

“parent's child" (Japanese; Wallace and Atkins 1969)

Preposition de, and á plus être ("to be")

La tante de Jean

“John's aunt" (French)

Ba-tatá ya nkénto na ngé (bó) zóla ngé

Pl-father of sg-wife of you (they) like you

"Your wife's father's brothers like you!" (Kikongo-Kituba; Mufwene $1985: 275)$

\section{Marking on neither head nor dependent}

(j) Juxtaposition

bin is-sultán

son DEF-king

“The king's son" (Maltese; Jonsson 2001:1210)

(k) Proprial article

Sa'ou va'ai i-a tina

PAST I see to-PROP mother

"I saw my mother." (Samoan; Dahl and Koptjevskaja-Tamm 2001:206) 
'n Per [name]

'n far [father] (Northern Swedish; Dahl and Koptjevskaja-Tamm 2001:206)

(1) Possessive pronouns

her aunt (English)

sa tante ("his/her aunt") (French)

mon pare my father (inalienable)

a meva casa my house (alienable) (Catalan; Dahl and Koptjevskaya-Tamm 2001:209)

Dakaseîimoók îmî oókeén

Dakaseîimoók's his/their mother

“Dakseîimoók’s mother."

áatuúm îmî aláte

my father his/their x-cous

“my father's cross-cousin.” (Telefol; Healey 1962:25) 
Figure 1 Dja:wa's drawing of Yolngu matri-sequences.

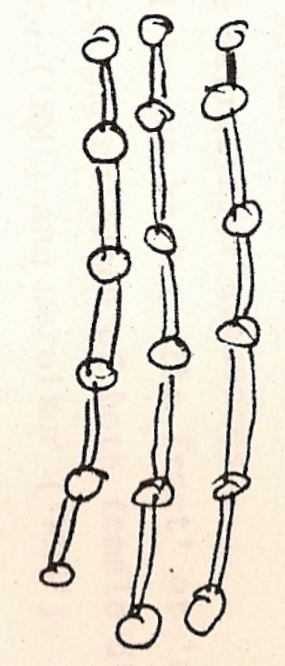

Figure 2 Lao gesture-diagrams of genealogical relations A (Source: Enfield 2005).

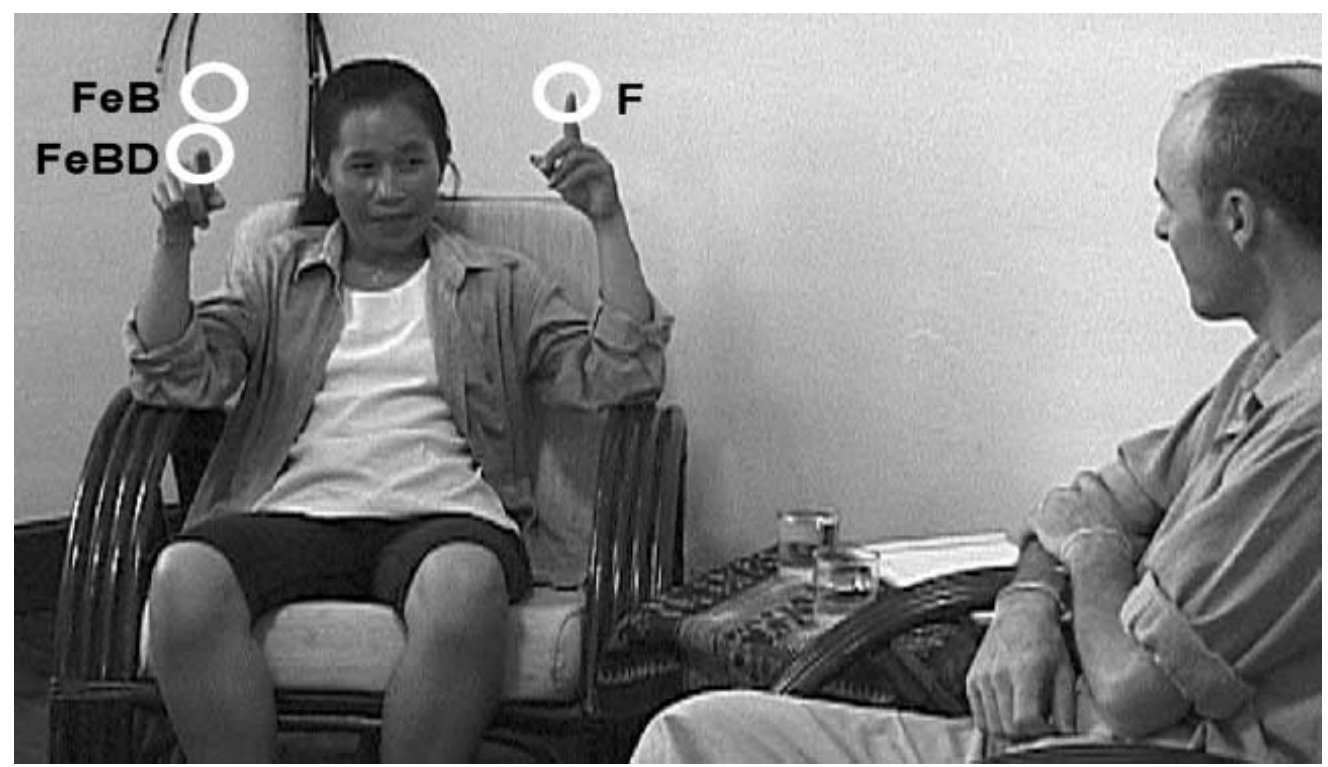


Table 2 Matri-sequences of Yolngu kin terms represented in Figure 1

$\begin{array}{ccc}\text { mumu (FM/MFZ) } & \text { ma:ri (MM) } & \text { mumalkur (MMMBD) } \\ \| & \| & \| \\ \text { mukul ba:pa }(\mathrm{FZ}) & \text { nga:rndi }(\mathrm{M}) & \text { mukul rumaru }(\mathrm{MMBD}) \\ \| & \| & \| \\ \text { dhuway }(\mathrm{FZD}) & \text { yapa }(\mathrm{Z}) & \text { galay }(\mathrm{MBD}, \mathrm{MMBDD}) \\ \| & \| & \| \\ \text { gurrung }(\mathrm{FZDD}) & \text { waku }(\mathrm{wD}) & \text { ga:thu }(\mathrm{mD} / \mathrm{BD}) \\ \| & \| & \| \\ \text { dhumun.gur }(\mathrm{FZDDD}) & \text { gutharra }(\mathrm{wDD}) & \text { gaminyarr }(\mathrm{mDD}) \\ \| & \| & \| \\ \text { mukul rumaru('MBDD') } & \text { nga:rndi ('M') } & \text { mukul ba:pa }\end{array}$

Figure 3. Lao gesture-diagrams of genealogical relations B

(Source: Enfield 2005).

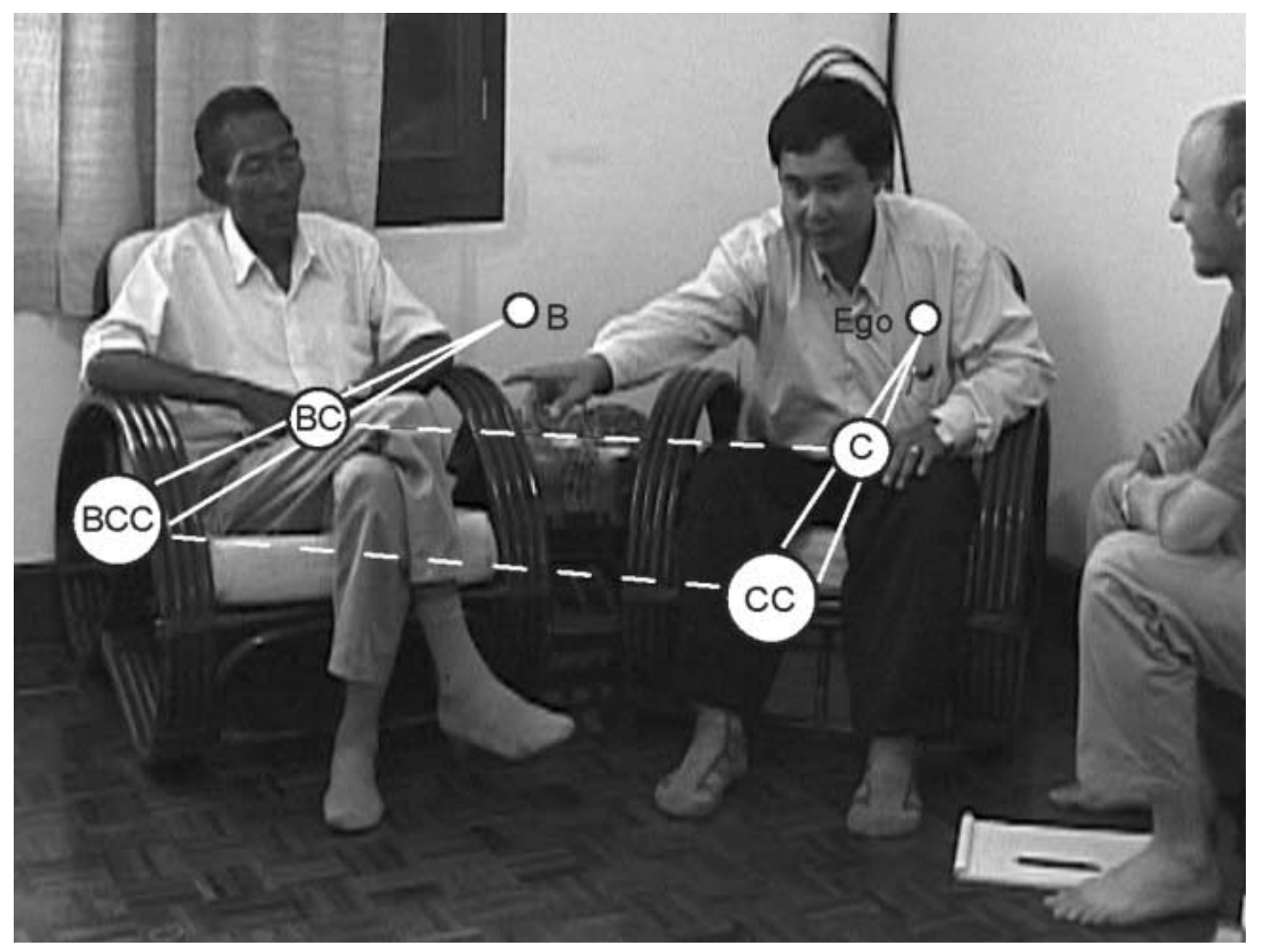




\section{Captions}

Table 1. Means of indicating a connection between propositus and referent

Figure 1. Dja:was drawing of Yolngu matri-sequences.

Figure 2. Lao gesture-diagrams of genealogical relations A (Source: Enfield 2005).

Table 2 . Matri-sequences of Yolngu kin terms represented in Figure 1

Figure 3. Lao gesture-diagrams of genealogical relations B (Source: Enfield 2005). 